KCP-613-5283

Distribution Category UC-706

Approved for public release; distribution is unlimited.

\title{
THICK FILM FABRICATION OF
}

\section{ALUMINUM NITRIDE MICROCIRCUITS}

L. H. Perdieu

Published March 1994

Final Report

L. H. Perdieu, Project Leader

Project Team:

S. W. Bandler

C. W. Boehning

M. A. Cunningham

L. W. McWilliams

P. M. Mizik

H. A. Morgenstern

J. E. Smoot

D. R. Swift

L. E. Warner 


\section{Contents}

$\begin{array}{ll}\text { Section } & \text { Page }\end{array}$

Abstract $\ldots \ldots \ldots \ldots \ldots \ldots \ldots \ldots \ldots \ldots \ldots \ldots \ldots \ldots \ldots$

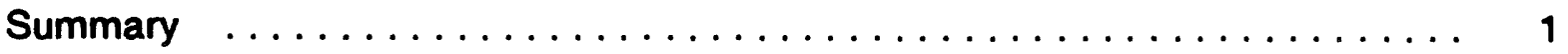

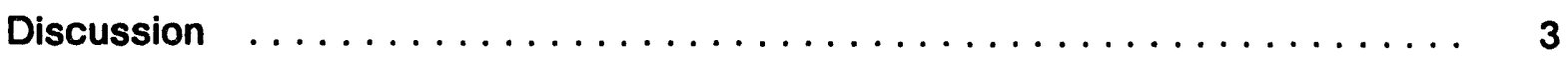

Scope and Purpose $\ldots \ldots \ldots \ldots \ldots \ldots \ldots \ldots \ldots \ldots \ldots \ldots \ldots \ldots$

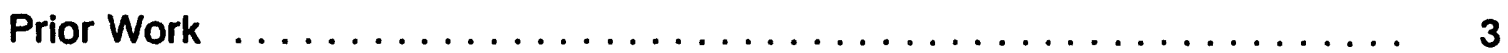

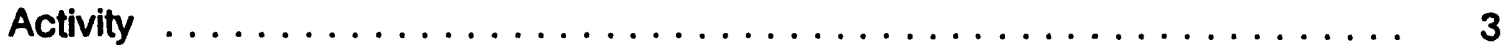

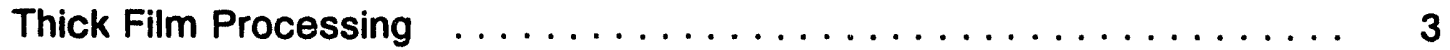

Analysis of AlN Thick Film Inks $\ldots \ldots \ldots \ldots \ldots \ldots \ldots \ldots$

Analysis of AIN Ceramic Substrates $\ldots \ldots \ldots \ldots \ldots \ldots$

Analysis of Assembly Techniques . . . . . . . . . . . . . . 12

Analysis of Laser Scribing/Machining Techniques $\ldots \ldots \ldots \ldots \ldots$

Analysis of Resistors $\ldots \ldots \ldots \ldots \ldots \ldots \ldots \ldots \ldots \ldots \ldots$

Thermal Performance Results $\ldots \ldots \ldots \ldots \ldots \ldots \ldots$

Accomplishments $\ldots \ldots \ldots \ldots \ldots \ldots \ldots \ldots \ldots \ldots \ldots \ldots \ldots \ldots \ldots$

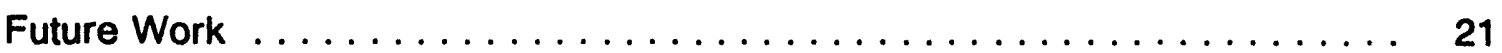

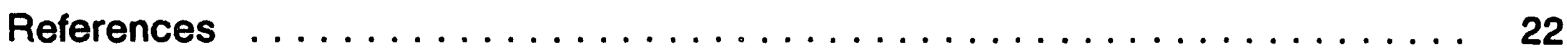

Appendix. Test Data for AIN Microcircuits $\ldots \ldots \ldots \ldots \ldots \ldots \ldots$ 


\section{Illustrations}

Figure

Page

1 Aluminum Nitride Power Hybrid on Sheet of AIN ... . . . . . . . . . 4

2 Furnace Profile for Aluminum Nitride Materials $\ldots \ldots \ldots \ldots \ldots$

3 Thick Film Resistor Test Pattern $\ldots \ldots \ldots \ldots \ldots \ldots \ldots \ldots$

4 Thick Film Conductor Test Pattern $\ldots \ldots \ldots \ldots \ldots \ldots \ldots \ldots \ldots$

5 Photomicrograph of Dielectric Blisters $\ldots \ldots \ldots \ldots \ldots \ldots$

6 Metal Adhesion Failures $\ldots \ldots \ldots \ldots \ldots \ldots \ldots \ldots$

$7 \quad$ Stability Versus Furnace Profiles $\ldots \ldots \ldots \ldots \ldots \ldots \ldots \ldots \ldots$

8 Average Stability (new furnace profile) $\ldots \ldots \ldots \ldots \ldots \ldots \ldots$

9 Stability at Different Stages of Testing $\ldots \ldots \ldots \ldots \ldots \ldots \ldots \ldots$

$10 \quad 10,000$ Ohm Resistor Stability (trimmed versus untrimmed) $\ldots \ldots \ldots \ldots$

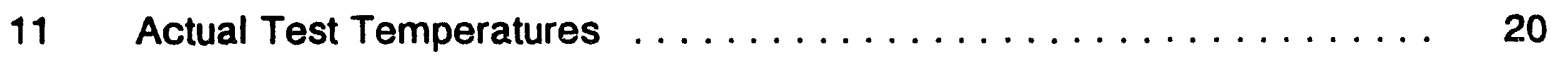

A-1 Pull Strength Versus Days After Cleaning $\ldots \ldots \ldots \ldots \ldots \ldots \ldots$

A-2 Pull Strength Versus Days After Cleaning, After Thermal Aging . . . . . 25

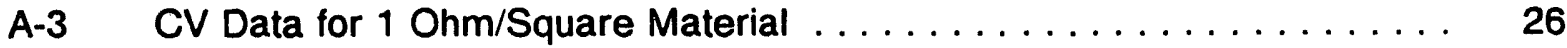

A-4 Histogram for CV Data for 1 Ohm/Square Material . . . . . . . . 27

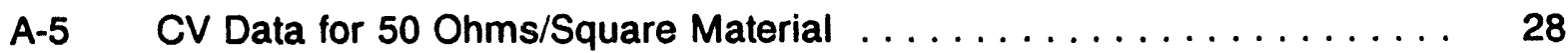

A-6 Histogram for CV Data for 50 Ohms/Square Material . . . . . . . . . 29

A-7 CV Data for 1,000 Ohms/Square Material $\ldots \ldots \ldots \ldots$

A-8 Histogram for CV Data for 1,000 Ohms/Square Material $\ldots \ldots \ldots . \ldots 31$

A-9 CV Data for 10,000 Ohms/Square Material $\ldots \ldots \ldots \ldots \ldots \ldots \ldots$

A-10 Histogram for CV Data for 10,000 Ohms/Square Material . . . . . . . 33 


\section{Tables}

Number

Page

1 Properties of Aluminum Oxide Versus Aluminum Nitride $\ldots \ldots \ldots \ldots$

2 Pull Strength Before and After Humidity Aging $\ldots \ldots \ldots \ldots \ldots \ldots$

3 Pull Strength After Multiple Conductor Firings $\ldots \ldots \ldots \ldots \ldots$

4 Substrate Camber Before and After Drilling Holes ............. 11

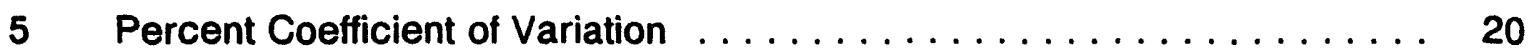

A-1 Pre-established Requirements for AIN Thick Film Hybrid Materials . . . 34 


\section{Abstract}

A new substrate material, aluminum nitride (AIN), and 11 new thick film inks were analyzed to determine their chemical compatibility, their electrical properties, their mechanical properties, and their overall suitability for use in the manufacturing of high-power microcircuits with efficient thermal properties. Because high-power chips emit a great deal of heat in a small surface area, a new substrate material was needed to dissipate that heat faster than the substrate material currently in use. Overall, the new materials were found to be acceptable for accomplishing this purpose.

\section{Summary}

Aluminum nitride was evaluated as a thick film substrate material for the following reasons: (1) its thermal conductivity is seven times greater than that of the standard substrate material (aluminum oxide); (2) it is nontoxic and can be used in high-power applications with little risk to safety, ${ }^{1}(3)$ its thermal coefficient of expansion (TCE) closely matches the TCE of silicon and gallium arsenide, making it useful for direct mounting of large VLSI dies; and (4) it uses similar processing and the same capital equipment as standard thick film printing.

Through a joint development effort by The Carborundum Company. The Ferro Corporation, and AlliedSignal Inc., Kansas City Division (KCD), a processing capability to manufacture AIN microcircuits with efficient thermal properties for high-power applications was developed. Through the use of infrared thermal scanning, it was determined that the circuit operating temperature was reduced by $24^{\circ} \mathrm{C}(80 \%$ reduction) when AIN ceramic was substituted for the standard substrate material (aluminum oxide) in a complex thick film multilayer circuit.

The test vehicle used for this technology transfer partnership was the Logic
Assembly for the T/R Module in support of KCD's Advanced Radar Group. The Logic Assembly has a high level of integration. This results in severe thermal management problems that limit the module's operation to room temperature when conventional substrate materials (such as aluminum oxide) are used. With the use of a high thermal conductivity substrate (AIN), thermal problems were resolved.

New thick film inks were evaluated because standard inks reacted chemically with aluminum nitride substrates, resulting in poor metallization bonding to the substrate and unpredictable resistor values.

Preliminary data indicated satisfactory results with most of the new materials. However, the capability to print resistors was abandoned because of the wide variation experienced in resistor values. A study was performed on standard resistor test patterns to determine the percent coefficient of variation (CV) of the new resistor inks. The average $\mathrm{CV}$ was found to be $11 \%$. The variation was worse than this on actual parts, which was attributed to the complexity of the design of the test vehicle application. When printed on test pattern samples, the new resistors could 
not be laser trimmed to nominal within a tolerance any tighter than 4 to 18 percent. Resistor stabilities averaged $3.8 \%$ (standard resistor stabilities average $0.2 \%)$.

The capability to print resistors on AIN should be pursued in a future study. The ink manufacturer is continually making improvernents to these resistors. Overall, the results of this evaluation were positive. The thermal conductivity of AIN substrates, the ability to metallize AIN, the ability to solder and wire bond to the metallization, the ability to laser contour/drill AIN, and the use of chip resistors will accommodate $90 \%$ of the Kansas City Division's current needs for better thermal management. 


\section{Discussion}

\section{Scope and Purpose}

The purpose of this project was to define a processing capability to manufacture highdensity, high-power microcircuits with efficient thermal properties. As the capabilities of radars have increased both in frequency/speed and complexity of signal processing, the power dissipation per unit area has increased rapidly. The power density for the Terminal Fix System (TFS) radar is already exceeding the capabilities of aluminum oxide, and future radars will have even more stringent requirements for efficient heat transfer.

\section{Prior Work}

Efforts to fabricate the high-density, highspeed T/R Logic Assembly using standard thick film materials resulted in an assembly that overheated when operating only slightly above room temperature. Until recently, aluminum oxide has been the main material choice for advanced electronic applications. However, with the trend toward higher circuit densities and faster operating speeds, thermal management has become a major concern.

\section{Activity}

Through a joint development effort by The Carborundum Company (manufacturer of AIN ceramics), The Ferro Corporation (manufacturer of thick film inks), and by AlliedSignal Inc., Kansas City Division (KCD), a processing capability to manufacture aluminum nitride (AIN) microcircuits with efficient thermal properties for high-power applications was developed.

The test vehicle used for this technology transfer partnership was the Logic Assembly for the Transmit/Receive (T/R) Module in support of KCD's Advanced Radar Group (see Figure 1). The Logic Assembly has a high level of integration. This results in severe thermal management problems that limit the module's operation to room temperature when conventional substrate materials (such as aluminum oxide) are used. The power transmitted from the final assembly has a peak power density of $2.17 \times 106 \mathrm{~W} / \mathrm{m}^{2}$ (1400 W/in.2) and an average power density of $7.13 \times 10^{3} \mathrm{~W} / \mathrm{m}^{2}$ (460 W/in.2). With the use of a high thermal conductivity substrate (AIN), thermal problems were resolved.

\section{Thick Film Processing}

Printing aluminum nitride networks is no different from printing aluminum oxide networks, except specially formulated pastes are used. These pastes contain glass systems that are compatible with aluminum nitride substrates. Standard resistor pastes reacted violently with aluminum nitride substrates. Outgassing caused large holes in the films. Resistor values were always high, sometimes as much a $800 \%$ over nominal value. This made predicting fired resistor values an impossible task. See Table 1 for a comparison of aluminum oxide and aluminum nitride properties.

The new glass systems were developed by The Ferro Corporation's Electronic Materials Division and they are proprietary. Screen selection remains the same for the 


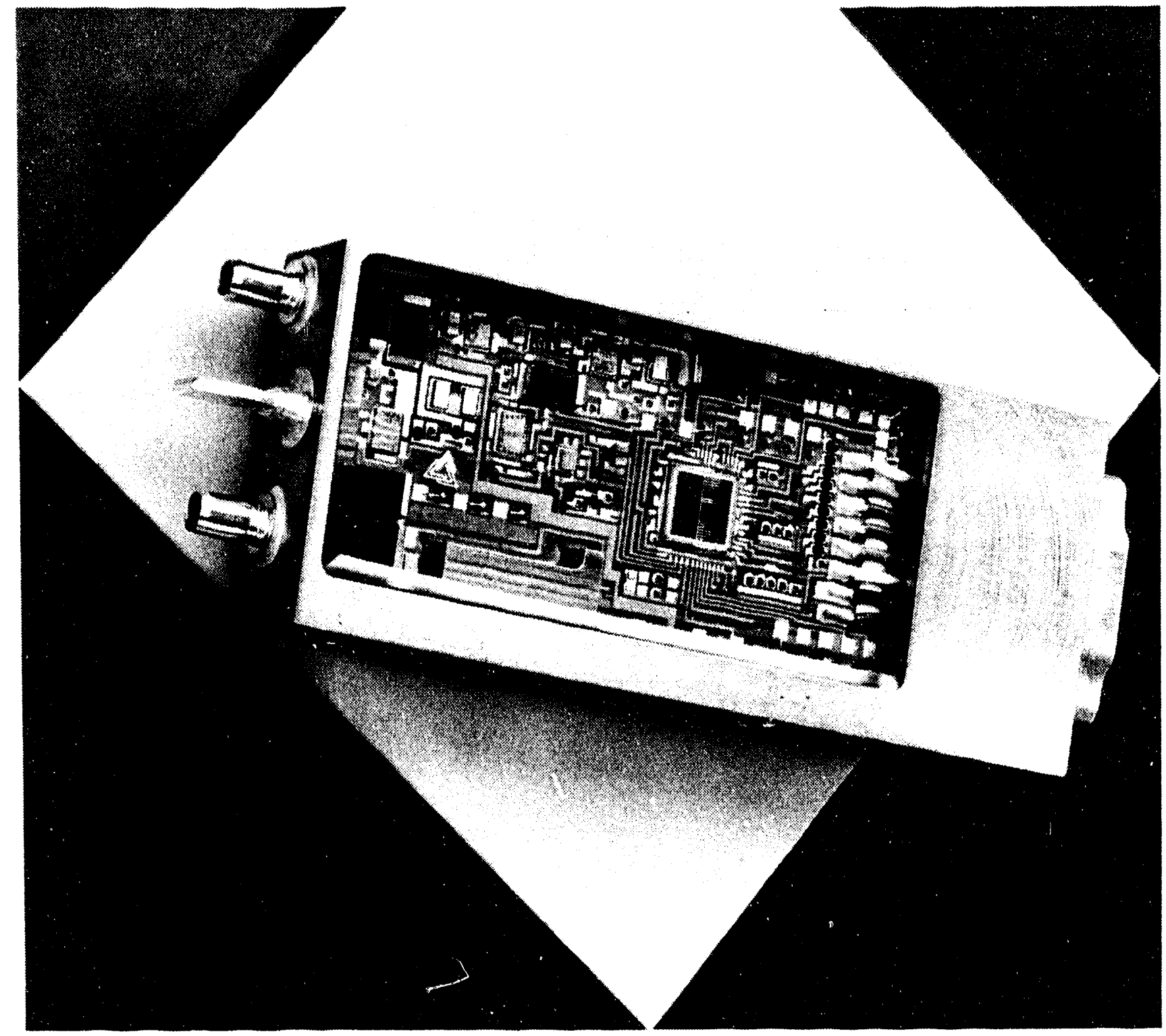

Figure 1. Aluminum Nitride Power Hybrid on Sheet of AIN

new pastes, and drying aluminum nitride networks is no different from drying aluminum oxide networks. ${ }^{2}$

Firing aluminum nitride networks requires a special furnace profile. The aluminum nitride profile is $\mathbf{4 2}$ minutes in duration with a 9 to 10 minute peak at $850^{\circ} \mathrm{C}$. See Figure 2 for the furnace profile.

\section{Anaiysis of AIN Thick Film inks}

Thick film materials have been developed that are compatible with aluminum nitride (AIN) substrates. A family of glass Compositions chemically compatible with AIN has been the key to the successful development of these pastes. The glass compositions also provide excellent wetting and bonding on AIN substrates. Using the 
Table 1. Properties of Aluminum Oxide Versus Aluminum Nitride

\begin{tabular}{||c|c|c||}
\hline Properties & Aluminum Oxide & Aluminum Nitride \\
\hline Thermal Conductivity & $25 \mathrm{~W} / \mathrm{m} \cdot \mathrm{K}$ & $170 \mathrm{~W} / \mathrm{m} \cdot \mathrm{K}$ \\
\hline Dielectric Constant & 9.9 & 8.8 \\
\hline TCE & $6.5(10 \mathrm{e}-6 / \mathrm{K})$ & $4.1(10 \mathrm{e}-6 / \mathrm{K})$ \\
\hline Resistivity & $10 \mathrm{e} 14 \mathrm{ohm} / \mathrm{cm}$ & $10 \mathrm{e} 14 \mathrm{ohm} / \mathrm{cm}$ \\
\hline
\end{tabular}

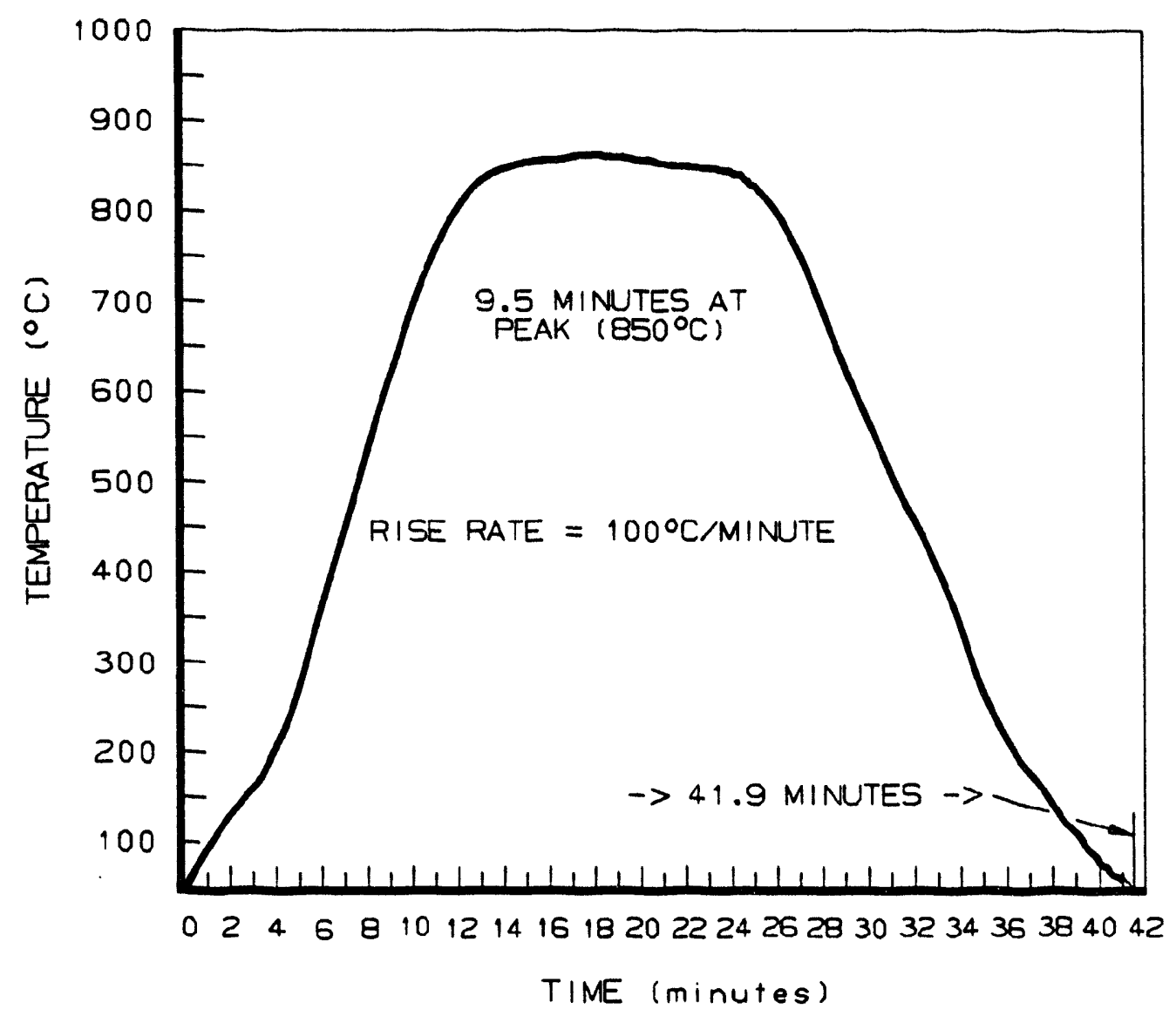

Figure 2. Furnace Profile for Aluminum Nitride Materials

developed glass compositions and reactive bonding compounds, the following pastes have been developed:

- A series of gold conductors including a gold paste (30-010) for wire bonding with gold wires, a mixed-bonded gold alloy paste $(30-011)$ for wire bonding with aluminum wires, a platinum gold (PtAu) paste (31-012) for use with tin lead $(\mathrm{Sn} / \mathrm{Pb})$ solder, and a low shrinkage gold paste (30-012) for via fills;

- A crossover and multilayer hermetic dielectric (10-054); and 
- Resistors including $1 \mathrm{ohm} / \mathrm{square}$ (89001), 50 ohms/square (89-005), 100 ohms/square (89-007), 1,000 ohms/square (89-008), and 10,000 ohms/square (89-009). ${ }^{3}$

A study was performed on standard resistor test patterns (see Figure 3) to determine the percent coefficient of variation (CV) of the new resistor inks. The average CV was found to be $11 \%$. The variation was worse than this on actual parts, which was attributed to the complexity of the design of the test vehicle application. When printed on test pattern samples, the new resistors could not be laser trimmed to nominal within a tolerance any tighter than 4 to 18 percent. Resistor stabilities averaged $3.8 \%$ (standard resistor stabilities average $0.2 \%$ ).

\section{Line Resolution}

A conductor trace having an artwork width of 15 mils was printed using platinum/gold paste 31-012 and an aluminum oxide platinum/gold paste. The width of the 31012 trace measured 7 percent less than the width of the aluminum oxide paste with the same printer setup (that is, 31-012 had slightly better resolution). Five mil lines and spaces were achieved with 31-012 paste using the conductor test pattern shown in Figure 4.

\section{Conductor Resistance}

Conductor resistance was measured using the 200-square electrical inspection pattern shown on the conductor test pattern in Figure 4. The conductor test pattern was printed 20 times for each conductor paste using a 325-mesh screen. The average resistivity for 31-012 was 22 milliohms/ square. The average resistivity for 30-010 was 3.5 milliohms/square.

\section{Solderabillty}

The conductor test pattern shown in Figure 4 was printed 40 times with 31-012 and then dipped into $63 / 37 \mathrm{Sn} / \mathrm{Pb}$ solder. Wettability was $100 \%$.

\section{Bonding Strength of Gold Film}

The bonding strength of the platinum/gold film to the aluminum nitride substrate was tested by a soldered wire pull test performed on pads that were 80 mils by 80 mils. Wires were attached to 20 pads by dipping in $63 / 37 \mathrm{Sn} / \mathrm{Pb}$ solder. The wires were then pulled at a $90^{\circ}$ angle. The average pull strength was $6.8 \mathrm{lb}$, with 0 out of 20 pulls being below $2 \mathrm{lb}$, the minimum acceptable pull strength. After humidity aging $\left(85^{\circ} \mathrm{C} / 85 \% \mathrm{RH} / 1000\right.$ hours), the average pull strength was $3.8 \mathrm{lb}$, with 3 out of 20 pulls being below $2 \mathrm{lb}$ (see Table 2).

A test was run to determine the effect of multiple conductor firings on pull strengths comparing AIN parts (31-012) to alumina parts. After 20 conductor firings, the AIN parts had an average pull strength of $4.3 \mathrm{lb}$ and the alumina parts had an average pull strength of $4.2 \mathrm{lb}$ (see Table 3).

\section{Reactivity}

During the fabrication of the Logic Networks, a reaction between the gold conductor (30-010 for gold wire bonds) and the dielectric (10-054) was observed. As with any multilayer application, the networks experienced multiple hightemperature firings. Single printed dielectric (solder stops) were printed over the 30-010 gold conductor which was printed directly over AIN. After five or six high-temperature firings, the single printed dielectric began to blister (see Figure 5).

Three separately fired layers of dielectric were printed between each conductor level of the Logic Networks (40 to $45 \mu \mathrm{m}$ total 


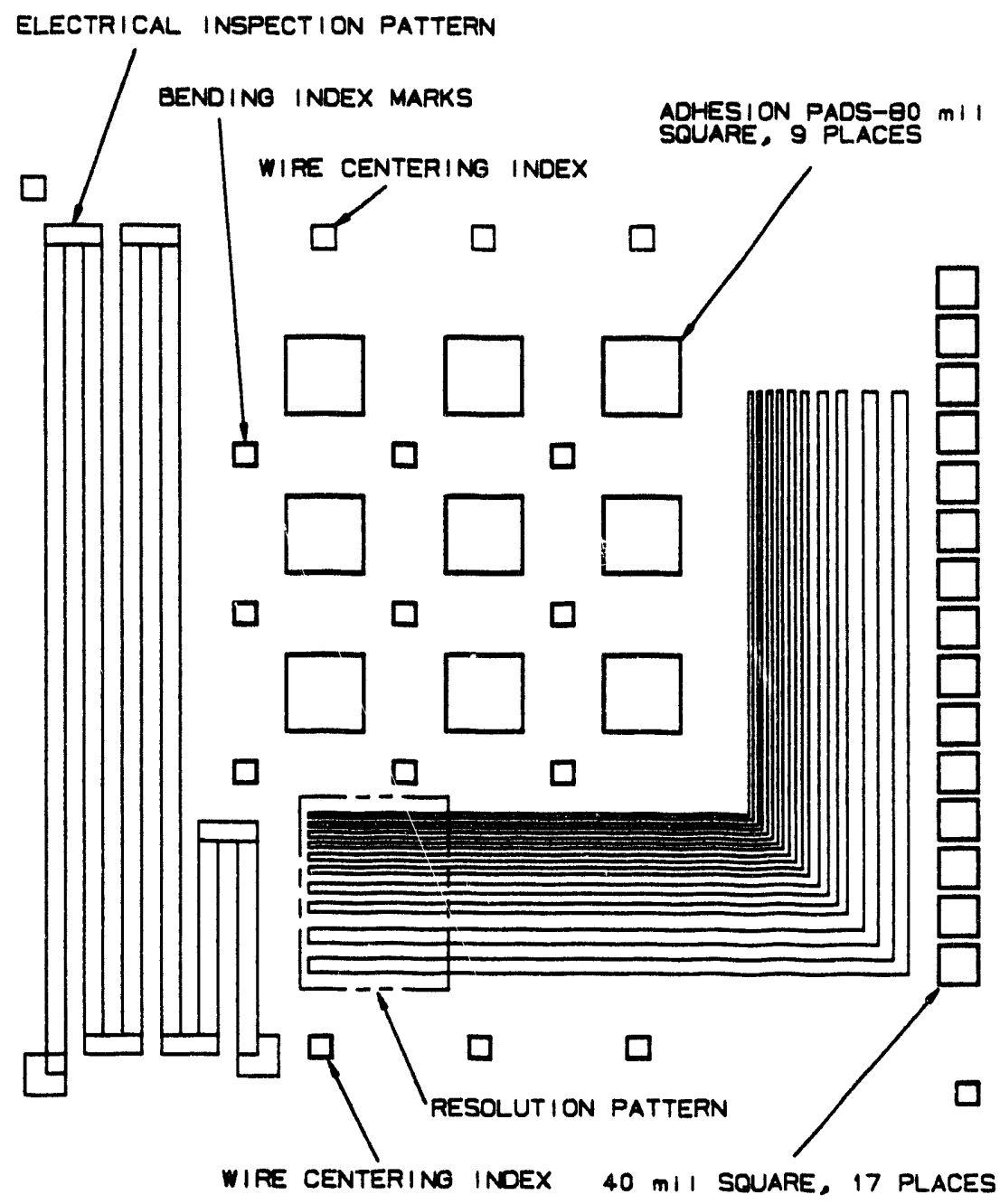

Figure 3. Thick Film Resistor Test Pattern

thickness). Triple-printed dielectric over 30-010 gold conductor did not blister after multiple high-temperature firings. This suggests that multiple firings plus the presence of air at the immediate interface between 30-010 gold conductor and 10-054 dielectric may be necessary for the reaction between these materials to occur.

Single printed solder stops on networks fabricated at the same time with a different gold conductor (30-011 for aluminum wire bonds) and 10-054 dielectric did not blister after multiple high-temperature firings.
In applications involving multiple hightemperature firings, 30-011 gold has significantly better adhesion than 30-010 gold. The bonding strength of the gold film to the aluminum nitride substrate was tested on actual parts fabricated by Ferro. The pull test results showed a significant difference between the bonding strength of the gold for gold wire bonds $(30-010)$ and the bonding strength of the gold for aluminum wire bonds (30-011).

Nickel-plated gold lead frames were attached to 28 pads on actual parts using $50 / 50 \mathrm{~Pb} / \mathrm{ln}$ solder. Then, the lead frames were pulled at a $90^{\circ}$ angle. The average 


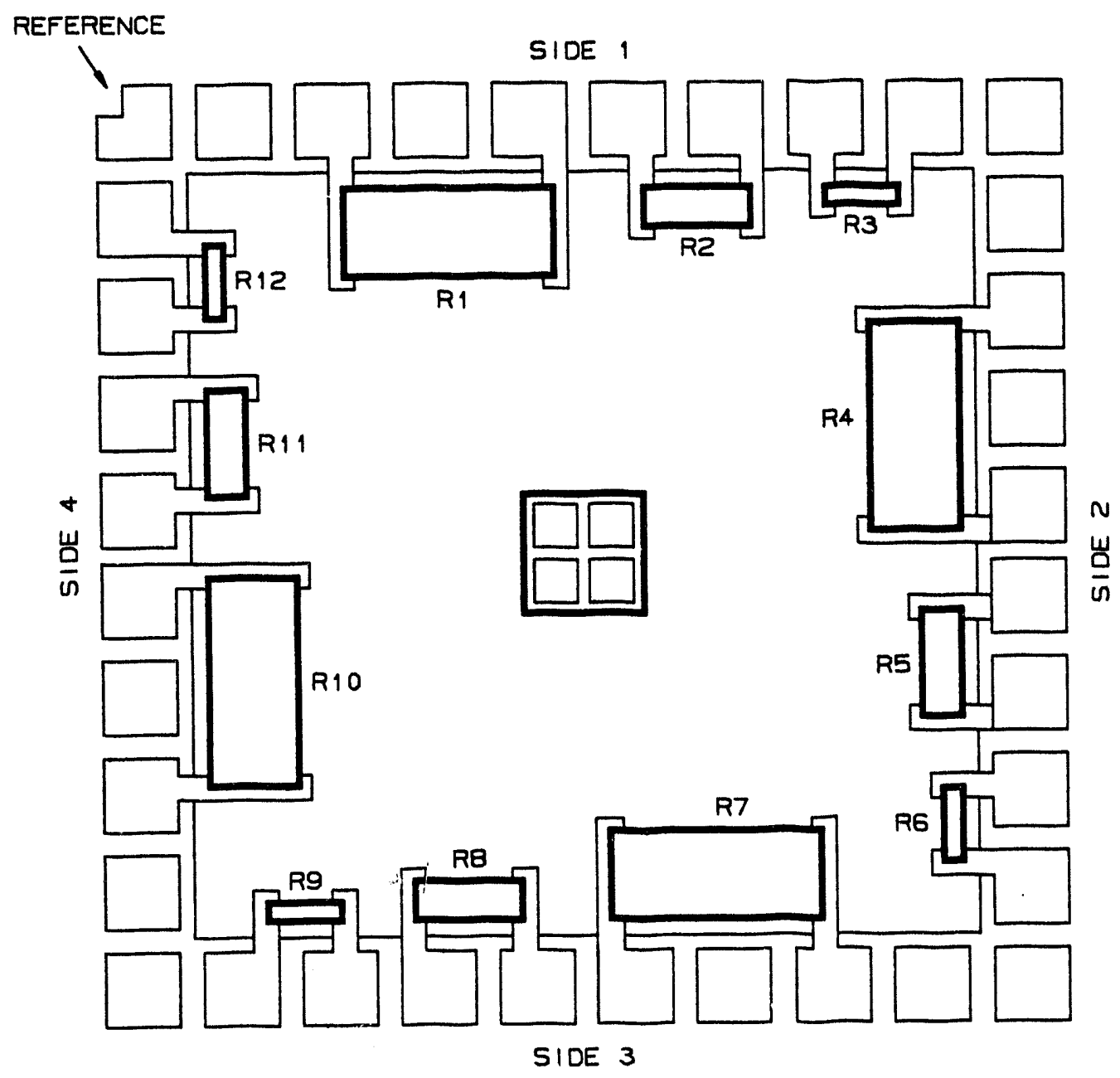

Figure 4. Thick Film Conductor Test Pattern

pull strength for 30-010 was 200 grams. The chief cause of failure was solder pad metallization failure; that is, the metallization peeled away from the AIN. For 30-011, the average pull strength was 435 grams and the chief cause for failure was the lead frame peeled from the solder. These parts experienced over 20 hightemperature firings at $850^{\circ} \mathrm{C}$ before pull testing.

\section{Analysis of AIN Ceramic Substrates}

\section{Thermal Conductivity}

The thermal conductivity (TC) of a substrate metallized with thick-film conductor material is lower than a bare AIN substrate. The thermal conductivity of a bare substrate was measured to be $198 \mathrm{~W} / \mathrm{m} \cdot \mathrm{K}$, a typical value for AIN. Then a uniform coating of thick film metallization was squeegeed over the substrate and fired. The thermal conductivity of the metallized substrate was measured at $135 \mathrm{~W} / \mathrm{m} \cdot \mathrm{K}$ 
Table 2. Pull Strength Before and After Humidity Aging

\begin{tabular}{||c|c|c|c|c|c||}
\hline \multirow{2}{*}{ Material } & \multirow{2}{*}{$\begin{array}{c}\text { Type of } \\
\text { Cleaning }\end{array}$} & \multicolumn{2}{c|}{$\begin{array}{c}\text { Before } \\
\text { Humidity } \\
\text { Aging }\end{array}$} & \multicolumn{2}{c||}{$\begin{array}{c}\text { After } \\
\text { Humidity } \\
\text { Aging }\end{array}$} \\
\cline { 3 - 6 } & & Average & $\begin{array}{c}\text { Standard } \\
\text { Deviation }\end{array}$ & Average & $\begin{array}{c}\text { Standard } \\
\text { Deviation }\end{array}$ \\
\hline $\mathrm{AIN}$ & No Clean & 5.8 & 1.51 & 3.1 & 0.89 \\
\hline & Standard Clean & 6.8 & 1.96 & 3.8 & 1.66 \\
\hline & Alternate Clean & 6.6 & 0.99 & 3.4 & 1.24 \\
\hline & & & & & 1.4 \\
\hline $\mathrm{Al}_{2} \mathrm{O}_{3}$ & No Clean & 4.4 & 1.13 & 1.0 .93 \\
\hline & Standard Clean & 4.2 & 1.05 & 1.0 & 0.53 \\
\hline & Alternate Clean & 4.4 & 0.85 & 1.2 & 0.77 \\
\hline
\end{tabular}

Table 3. Pull Strength After Multiple Conductor Firings

\begin{tabular}{|c|c|c|c|c|c||}
\hline \multirow{2}{*}{ Material } & \multirow{2}{*}{$\begin{array}{c}\text { Firing } \\
\text { Condition }\end{array}$} & \multicolumn{2}{c|}{$\begin{array}{c}\text { Before } \\
\text { Thermal } \\
\text { Aging }\end{array}$} & \multicolumn{2}{c|}{$\begin{array}{c}\text { After } \\
\text { Thermal } \\
\text { Aging }\end{array}$} \\
\cline { 3 - 6 } & & Average & $\begin{array}{c}\text { Standard } \\
\text { Deviation }\end{array}$ & Average & $\begin{array}{c}\text { Standard } \\
\text { Deviation }\end{array}$ \\
\hline $\mathrm{AlN}$ & No Firings & 4.0 & 0.52 & 2.5 & 0.84 \\
\hline & 20 Firings & 4.3 & 0.78 & 0.8 & 1.32 \\
\hline $\mathrm{Al}_{2} \mathrm{O}_{3}$ & & & & & \\
\hline & No Firings & 3.9 & 0.79 & 2.6 & 1.18 \\
\hline
\end{tabular}

using the short-pulse-length TEA $\mathrm{CO}_{2}$ laser technique.

In multilayer thick films, heat-generating components must go down on the substrate level because the thermal conductivity of a substrate printed with a coating of dielectric is extremely poor$43 \mathrm{~W} / \mathrm{m} \cdot \mathrm{K}$.

\section{Oxide Growth}

Oxide growth per high-temperature firing $\left(850^{\circ} \mathrm{C}\right)$ is only 20 angstroms (acceptable). 


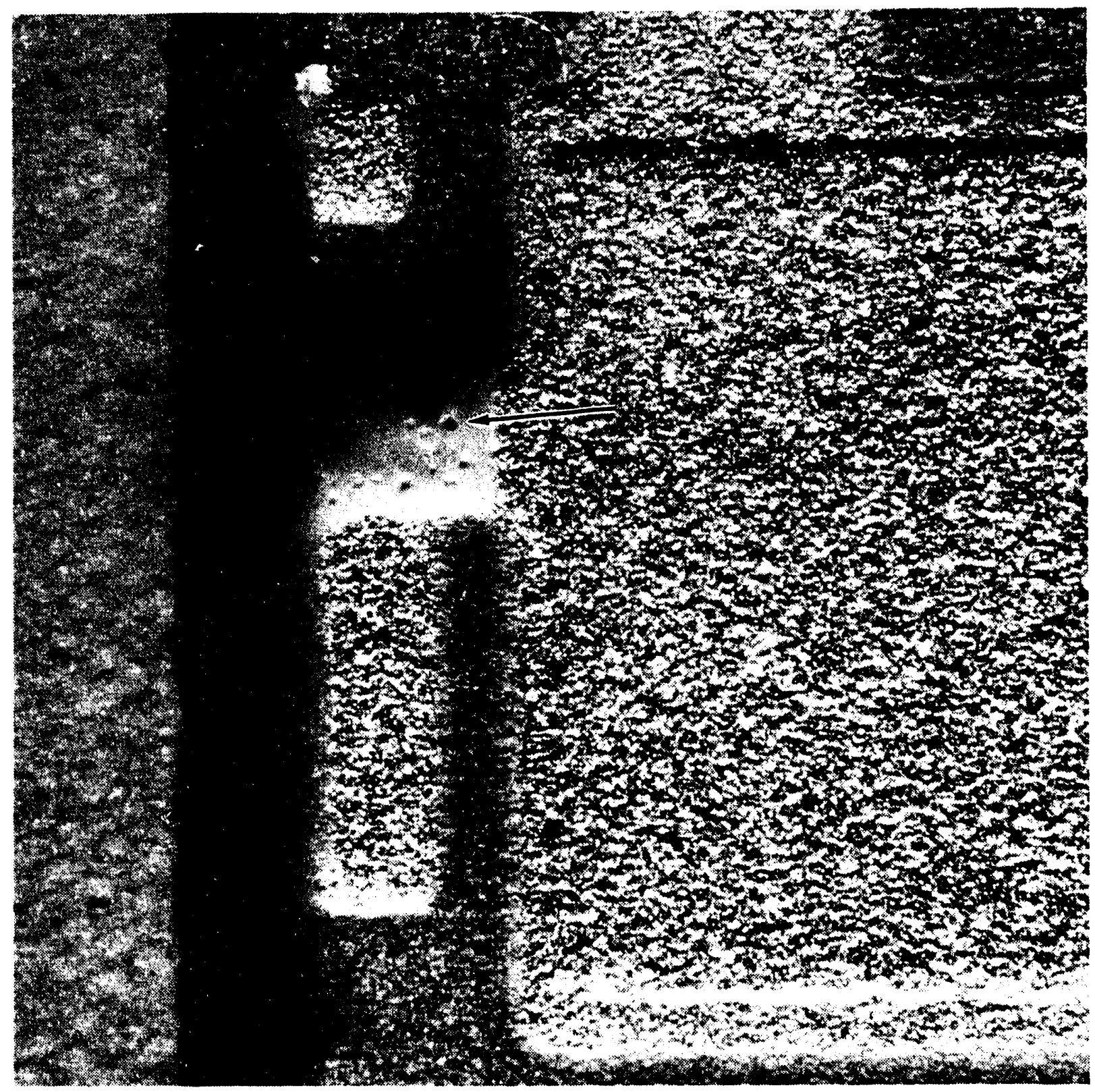

Figure 5. Photomicrograph of Dielectric Blisters

However, AIN substrates fired above $1100^{\circ} \mathrm{C}$ will oxidize. Because KCD's standard refire process (to anneal cracks caused by laser drilling) goes above $1100^{\circ} \mathrm{C}$, it is mandatory that AIN substrates bypass the refiring process.

\section{Camber}

Hole drilling has no effect on camber (see data, before and after hole drilling, in Table 4). Substrates should be $100 \%$ tested for camber prior to printing. 
Table 4. Substrate Camber Before and After Drilling Holes

\begin{tabular}{||c|c|c|c||}
\hline $\begin{array}{c}\text { Part } \\
\text { Identification }\end{array}$ & Before & After & Thickness \\
\hline 1 & 6.2 & 6.0 & 25.3 \\
\hline 2 & 16.3 & 16.9 & 25.9 \\
\hline 3 & 22.6 & 33.1 & 24.9 \\
\hline 4 & 7.8 & 7.6 & 26.6 \\
\hline 5 & 27.3 & 34.3 & 27.2 \\
\hline 6 & 16.6 & 23.4 & 27.1 \\
\hline 7 & 5.7 & 5.4 & 25.3 \\
\hline 8 & 8.3 & 4.9 & 25.9 \\
\hline 9 & 7.3 & 4.3 & 26.3 \\
\hline 10 & 5.1 & 4.0 & 27.1 \\
\hline 11 & 4.1 & 3.2 & 25.1 \\
\hline 12 & 4.8 & 6.1 & 26.8 \\
\hline
\end{tabular}

The following camber measurement technique is used at KCD. A height gage is drawn across the part to determine the high point. The distance from the high point to the top of the flat surface is measured (usi is a height gage). The average part thickness is subtracted from the high point distance to determine camber.

\section{Bending Strength}

Forty pieces of ceramic (20 were AIN and 20 were alumina) were put through a threepoint bend test. All pieces were the same length, width, and thickness. The AIN ceramics broke with $19 \%$ less force than the alumina ceramics.

\section{Cleaning}

AIN is compatible with the present KCD cleaning processes. This was determined by running three experiments. First the substrates were subjected to the individual portions of the present cleans to determine if there were any adverse interactions.

Second, the substrates were cleaned using the production processes and wire pull strength measured for those cleans. These results were then compared to no clean at all. Third, the time interval between cleaning and printing was investigated to determine if a timing specification would be required.

There are two production processes used to clean substrates at KCD. There is a "standard clean" that uses individual pieces of automated equipment and an "alternate clean" that is used when the automated equipment is down. The standard clean starts off with a Freon degrease; then the substrates go through a peroxide clean, followed by a D.I. water rinse, and finally a nitrogen dry. The alternate clean is a Freon degrease, an Igepal (surfactant) scrub, a D.I. water rinse, 
two peroxide cleans, two ultrasonic D.I. water cleans, then four D.I. water rinses, and finally a nitrogen tunnel dry.

The wire pull strength test used in these experiments consisted of cleaning the substrates as required, then printing them with Ferro 31-012 PUAu conductor material using the KCD conductor test pattern. These substrates next had wires soldered to them; the wires were then pulled on an Instron pull tester.

AIN substrates were subjected to individual portions of the cleans described above and then to the full process to ensure that there would be no adverse interactions with the chemicals or equipment involved. No adverse interactions occurred.

Next, the wire pull strength of AIN processed with these two cleans and how it compared to no clean was investigated. It was found that the wire pull strength exceeded the 2 pound pull strength specification for all three conditions. The best results were obtained with the standard clean; then came the alternate clean and no clean (see Table 2).

Finally, the interval between cleaning and printing was examined to determine its effect on wire pull strength. Several substrates were cleaned, and a group was printed each day for 10 days. The wire pull strength for these substrates oscillated over this time period but never developed a clear upward or downward trend. (See Figures A-1 and A-2 in the Appendix of this report.)

To summarize, AIN substrates were found to be compatible to the present KCD cleaning chemicals and equipment. Wire pull strengths for substrates cleaned using the present processes exceeded specifications. Finally, a timing specification is not required between cleaning and printing of AIN substrates.

\section{Analysis of Assembly Techniques}

\section{Thermosonic Gold Wire Bonding}

Sample substrates that were single-printed with gold conductor (30-010, which is suitable for gold wire bonding) were populated with 1-mil gold jumper wires. Standard parameters were used during the wire bonding process. Subsequent pull testing of the wires to destruction yielded normal pull strengths (average $=7.5$ grams, standard deviation $=1.17$ grams, minimum $=5$ grams) .

\section{Ribbon Bonding}

During the thermosonic bonding of $2 \times 5$ mil gold ribbons to single-printed gold conductor, metallization peeling occurred in over $50 \%$ of the bond sites (see Figure 6). Subsequent bonding and pull testing of double-printed gold conductors showed a much more stable bond zone and normal pull strengths (average $=126.5$ grams, standard deviation $=14.8$ grams, minimum $=80$ grams).

\section{Conductive and Nonconductive Epoxies}

Samples of a 230 mil square semiconductor die were attached to thick film gold conductors $(30-010)$ using both a conductive and a nonconductive epoxy. Shear tests of the die revealed that all shear strengths were over 19.6 kilograms and that there were no metallization lifts.

\section{Analysis of Laser Scribing/Machining Techniques}

\section{Laser Scribing}

The YAG laser scriber in the Microminiature Electronic Assembly Department 

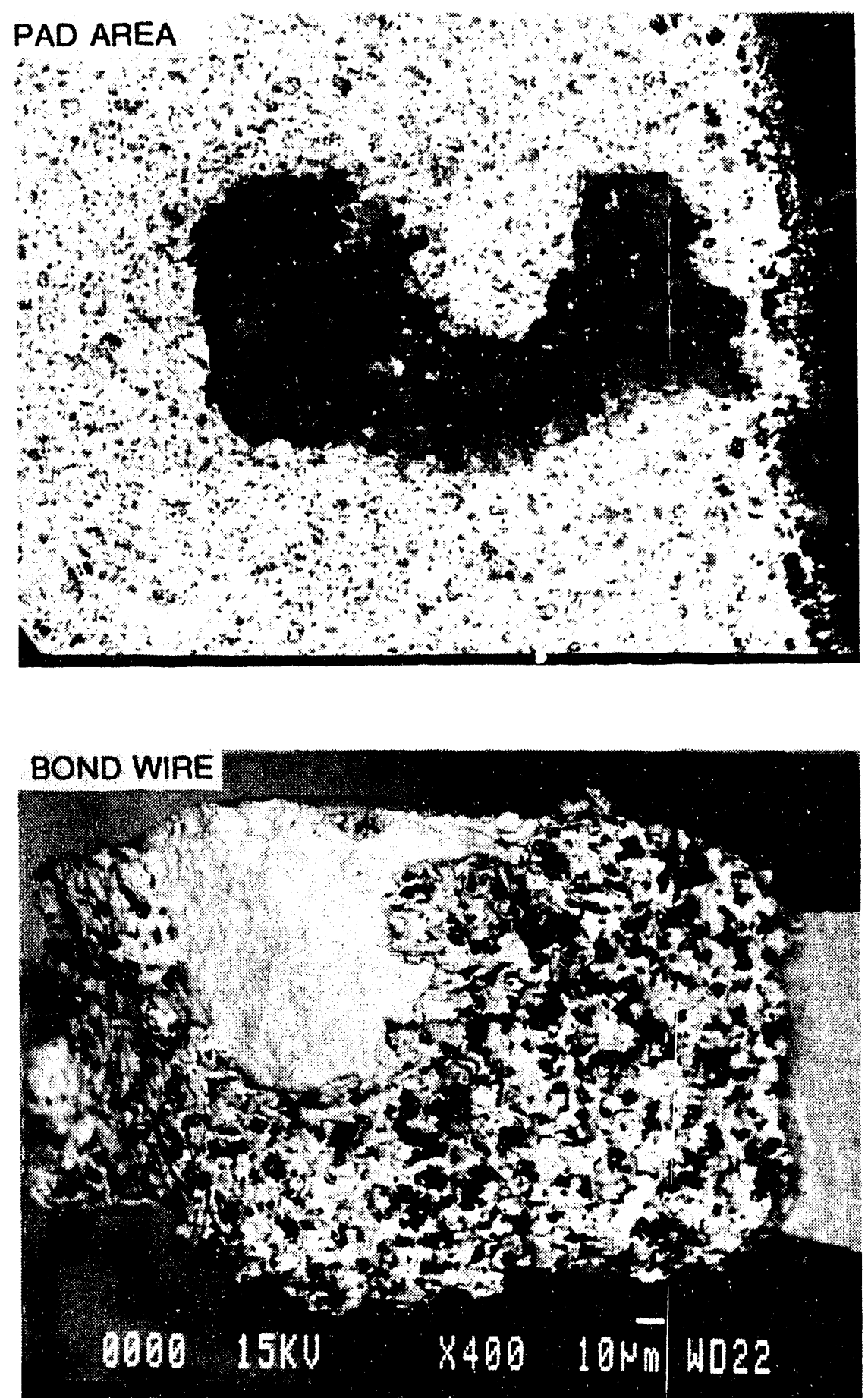

Figure 6. Metal Adhesion Failures 
at KCD does a fine job of scribing AIN ceramic substrates. Many substrates have been scribed and broken. The results have been excellent. The AIN ceramic breaks in a perpendicular fashion along the scribe lines. The breaks are very clean and accurate. The only drawback is that the scribe lines have a conductive aluminum track from the top of the ceramic surface to the bottom of the scribe (7 to 8 mils deep). If this conductive track is a problem on the front side, the substrates could be scribed on the back side with little or no accuracy loss.

\section{Laser Drilling}

$A \mathrm{CO}_{2}$ laser is more likely to cause thermal damage to AIN than to aluminum oxide because of the high absorption coefficient of AIN. Also, $\mathrm{CO}_{2}$ laser machining has to be performed with a cover gas $\left(\mathrm{O}_{2}\right)$ to limit the formation of aluminum. Because of the high absorption coefficient of AIN, the distance between holes must be doubled compared to machining aluminum oxide. The minimum hole diameter possible with a $\mathrm{CO}_{2}$ laser is 0.005 in. A hole cannot be placed as close to the edge of an AIN substrate as an aluminum oxide substrate because the AIN substrate may crack.

The $\mathrm{CO}_{2}$ laser driller in the Microminiature Electronic Assembly Department (400 watts) does a marginal job of drilling vias and cutouts in AIN. Many holes ranging from 5 mils upward have been drilled. The problem with this laser is that to get the power to do a good job on 25 mil thick AIN, the laser must be pulsed at $5000 \mathrm{~Hz}$. The laser manufacturer says that this laser should only be pulsed to $2000 \mathrm{~Hz}$ maximum. Pulsing the laser faster than $2000 \mathrm{~Hz}$ could lead to premature failure in certain components in the laser, but the bxact details of what would fail and when aie not known. It has been observed that sometimes when pulsing at $5000 \mathrm{~Hz}$, one of the laser tubes loses power, causing a power output drop. When this occurs, the AIN may crack. A method for preventing this occurrence has been discovered, but this may not be a final solution for this problem. A new lens and the addition of oxygen as a nozzle cover gas have both helped this process, but not enough to overcome the lack of power of the laser.

The holes made in the AIN by this laser appear free of aluminum, mostly because of the addition of the $\mathrm{O}_{2}$ cover gas. The holes have been observed under the scanning electron microscope and no radial cracking was evident.

In conclusion, this 400 -watt $\mathrm{CO}_{2}$ laser is underpowered for this job. It has shown that it can do a good job when it is working right. However, the possibility of causing a breakdown from over driving it is also a consideration. It is recommended that this laser be used only in emergency situations on small runs and that standard jobs be sent to an outside laser machining source.

\section{Analysis of Resistors}

\section{Stability}

At this time, two conclusions can be reached: (1) the resistors made from 100 ohms/square paste (89-007) are not stable enough to meet anticipated tolerances, and (2) the resistors made from $50 \mathrm{ohm} / \mathrm{square}$ paste (89-005) cannot have a tight tolerance $(<5 \%)$.

The graphs in Figure 7 show the average differences in stability, during accelerated aging, for untrimmed resistors made from $1,50,100,1,000$, and 10,000 ohms/square paste. In addition, the difference in stability because of firing profiles is compared.

Test samples for each resistor paste decade were prepared and fired using the standard profile (60 minute profile with an $850^{\circ} \mathrm{C}$ peak for 10 minutes). The value of 


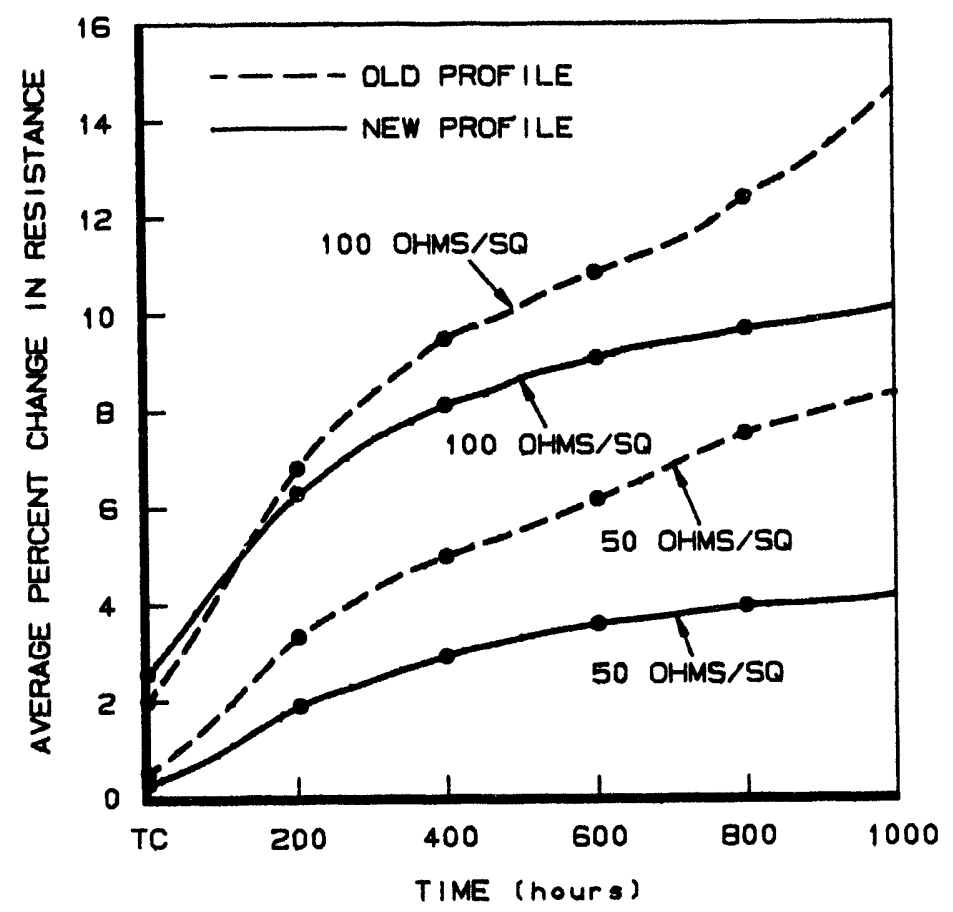

a. FOR 50 AND 100 OHMS/SO

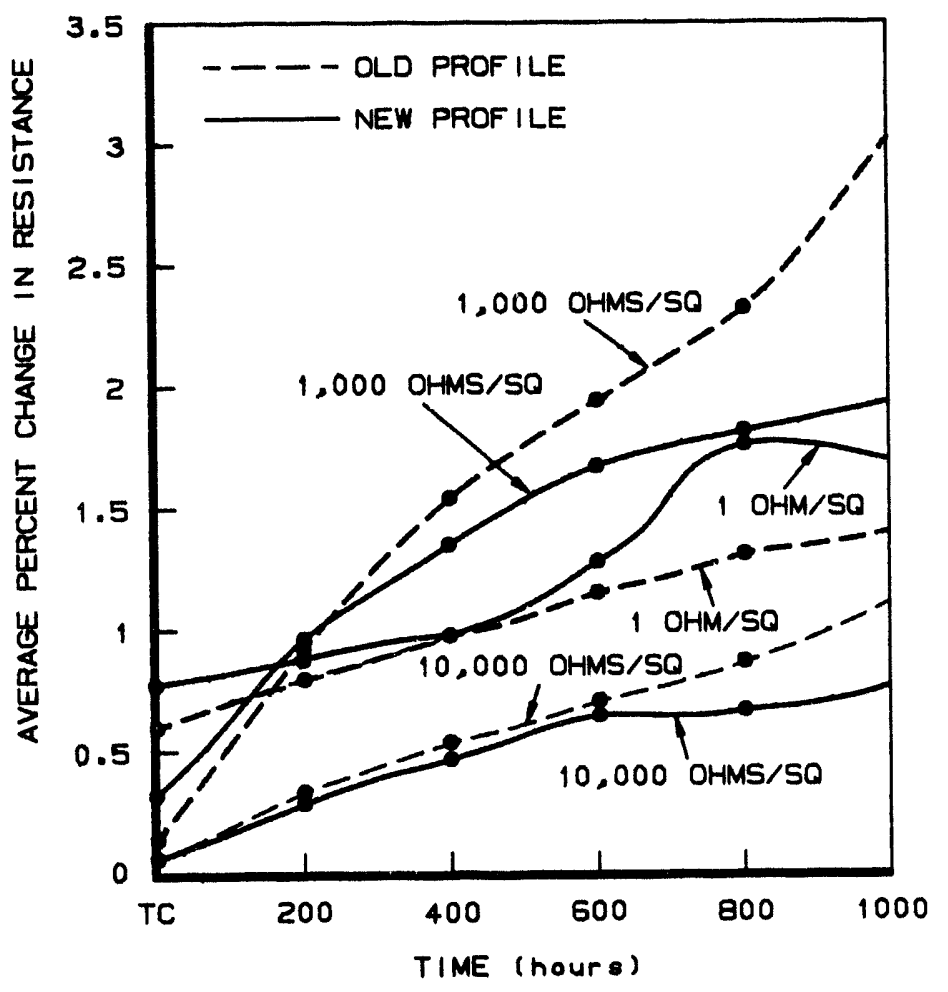

b. FOR 1, 1000, AND 10,000 OHMS/SO

Figure 7. Stability Versus Furnace Profiles 
each resistor on the sample was measured and recorded. Each untrimmed test sample was subjected to the following tests: 24 hour drift, temperature shock (25 to 268 to $25^{\circ} \mathrm{C}$ ), temperature cycle (-40 to $125^{\circ} \mathrm{C}$ for 10 cycles), and a 1,000 hour thermal aging test at $150^{\circ} \mathrm{C}$. The values of the resistors were measured after each test, and the percent change in value from the initial value was calculated. As can be seen in Figure 7, there is a considerable difference in stability between the 100 and 50 ohms/square pastes and the other pastes. This was not an expected result. The vendor suggested using a shorter firing profile.

Additional test samples were prepared, approximately 500 resistors for each paste decade. They were fired using the profile suggested by the vendor (see Figure 2). The same tests were performed on this group as before. The resulting percent change in resistor value is shown in Figure 7 for each paste. The resuits of the testing show an improvement in stability for $50,100,1,000$, and 10,000 ohms/square resistors.

A comparison in average stability for 1,50 , $100,1,000$, and 10,000 ohms/square untrinımed resistors fired with the suggested profile is shown in Figure 8. As can be seen, there is a large difference between the 100 ohms/square resistors and resistors made with the other paste decades. This data indicated, based on anticipated resistor tolerances, that resistors made with $100 \mathrm{ohms} / \mathrm{square}$ paste are not acceptable for use. The stability of the $\mathbf{5 0}$ ohms/square paste also limits the resistor tolerance for resistors made with this paste. Figure 9 further supports these conclusions. The average percent change, as well as the 3 sigma distribution, is shown for each paste decade for each test.

\section{Laser Trimming}

It is possible to YAG laser trim AIN resistors, but it is difficult in that the laser parameter range necessary to achieve a visually acceptable cut is very narrow compared to the trimming range for aluminum oxide resistors.

Figure 10 shows the difference in stability between trimmed 10,000 ohm resistors and untrimmed $10,000 \mathrm{ohm}$ resistors. For YAG laser trimming of AIN resistors, no substrate penetration should occur. Kerf width should be slightly wider than $50 \mu \mathrm{m}$. A cover gas is not used when trimming AIN resistors. It is recommended that a minimum resistor width be specified at $\mathbf{4 0}$ mils.

Auger electron spectroscopy profiles that were run at different points along the resistor kerf determined that no metallic aluminum could be detected. The points examined were all aluminum oxide when the profiles were terminated at a 12,000 angstrom depth.

\section{Percent Coefficient of Varlation}

Four hundred thirty-two resistors were printed at $25 \pm 2 \mu \mathrm{m}$ dried thickness (108 resistors for each paste decade) to determine the percent coefficient of variation. The resistors had a width of 50 mils and a length of 100 mils. See Figures A-3 through A-10 in the Appendix.

The percent coefficient of variation gives a comparative number for the variance in resistivity caused by the paste itself.

The percent coefficient of variation was calculated by dividing the standard deviation by the mean (see Table 5). The $\%$ CV for $89-001=11 \%, 89-005=14 \%$, $89-008=7 \%$, and $89-009=12 \%$. 


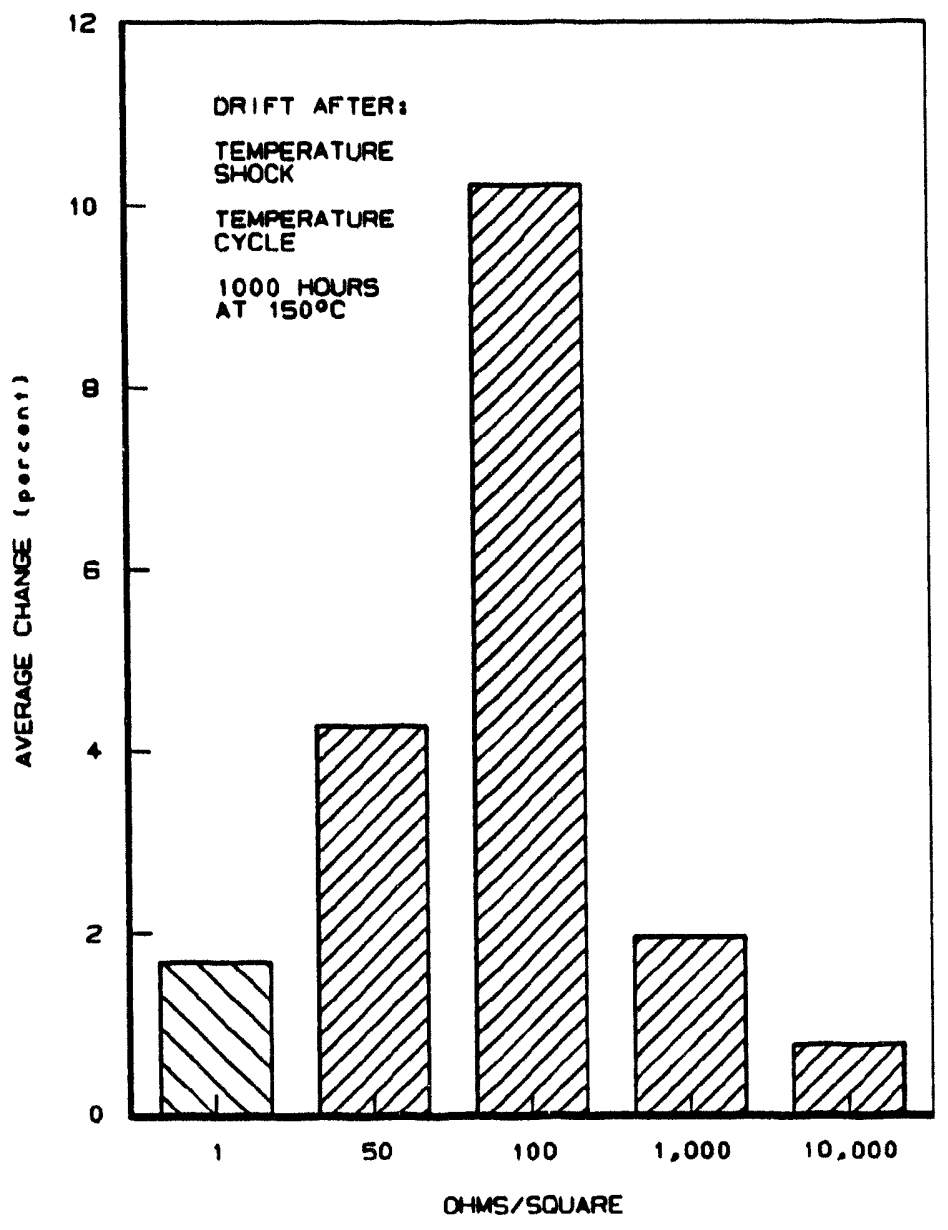

Figure 8. Average Stability (new furnace profile)

\section{Thermal Performance Results}

To experimentally verify the aluminum nitride substrate thermal performance in the actual T/R Module housing, two modules were built using logic assemblies made from aluminum nitride and alumina substrates. The substrate material thickness in both units was 25 mils. The logic assembly uses gold wire based chip and wire construction with solder attachment of all heat-generating components and conductive epoxy attachment of the remaining components.

To ensure that the same electrical loads were present in both units, precision $1 \%$ wire-wound resistors were used to simulate power demand of the RF assemblies that would normally be present in the T/R Module assembly. The power resistors were conductive epoxy bonded to the housing on the RF side to ensure that the heat generated by the resistors was conducted back into the housing. The load on the +8 volt transmitter regulator was set to 3.5 amperes (pulsed, 40 microsecond pulse width, $30 \%$ duty factor), the +5 volt receiver regulator load was 170 milliamperes (pulsed, 60 microsecond pulse width, $70 \%$ duty factor), and the -2.5 volt gate bias regulator load was 2.0 milliamperes.

To start data collection, the thermal chuck on the tester was set to $+65^{\circ} \mathrm{C}$ and a hand-held noncontact infrared thermal probe was used to measure the 


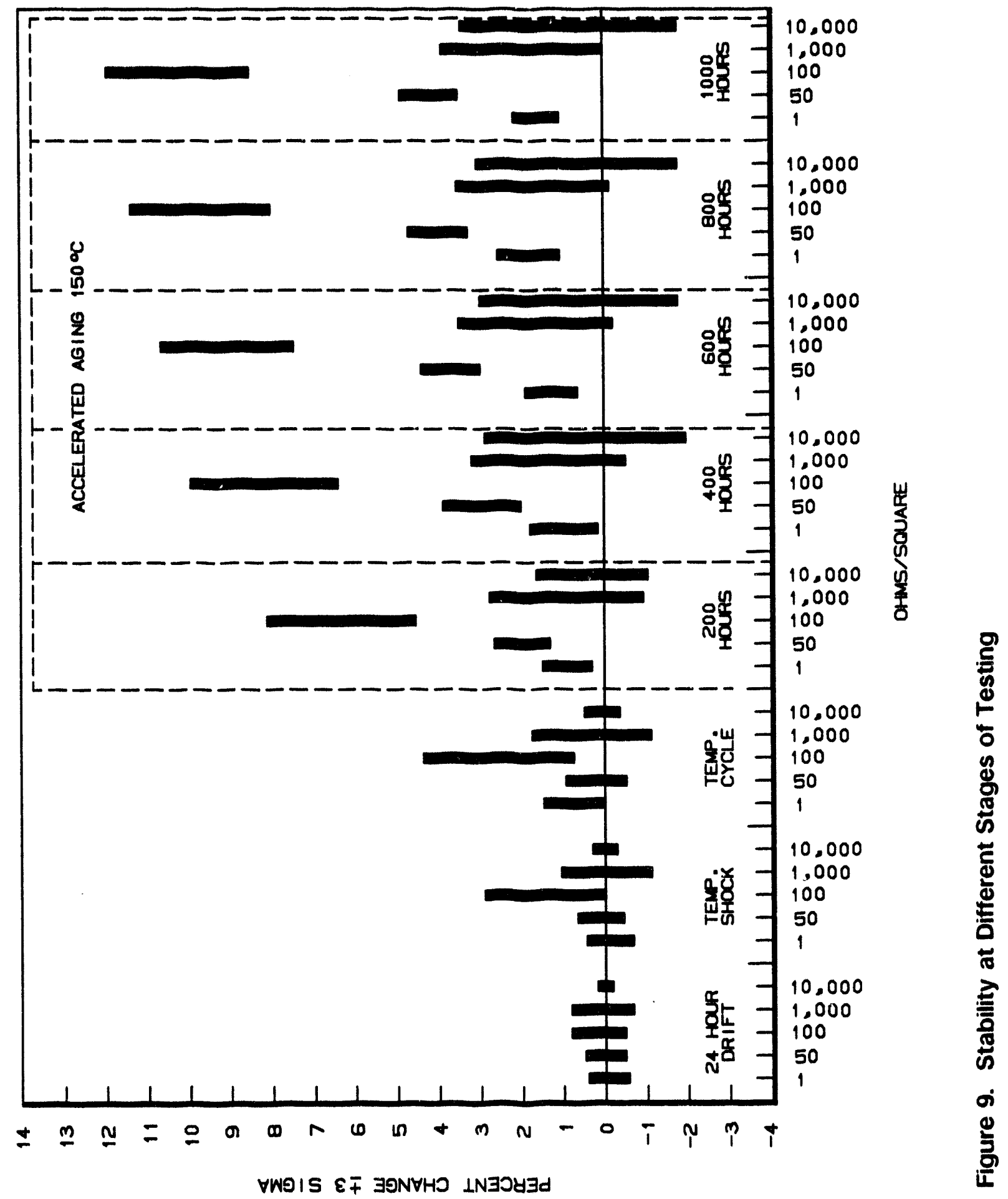




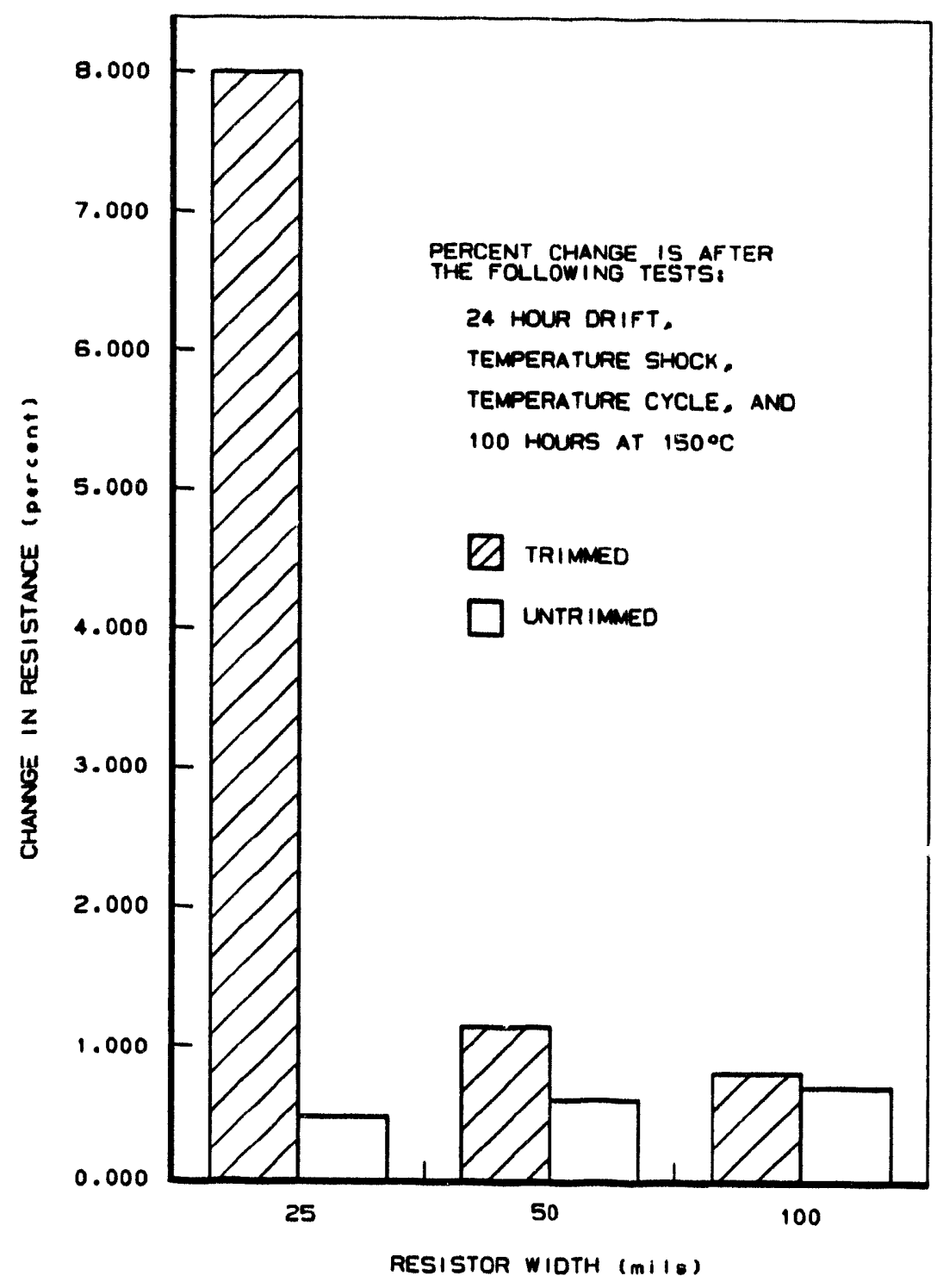

Figure 10. 10,000 Ohm Resistor Stability (trimmed versus untrimmed)

temperature of the thermal chuck and the unit. The unit was placed on the preheated chuck, and its warmup characteristics were observed as the unit warmed to $+65^{\circ} \mathrm{C}$ from room temperature. The unit was not powered during this sequence.

The aluminum nitride based logic assembly had worse case thermal gradients of $3^{\circ} \mathrm{C}$ across the face of the substrate during warmup. The alumina based logic assembly had gradients in the $15^{\circ} \mathrm{C}$ range. The lower gradients for AIN mean less mechanical stress on the surface mount parts during temperature transitions.

Using the thermal probe, the temperature on the top of the transmitter (TX) regulator (U1) was measured as the DC power was applied to the unit. The final stabilized temperature of the regulator was recorded for each type of substrate material. The actual test temperatures measured on the units are summarized in Figure 11. 
Table 5. Percent Coefficient of Variation

\begin{tabular}{||c|c|c|c|c||}
\hline Paste & $\begin{array}{c}\text { Average } \\
\text { Dry } \\
\text { Thickness } \\
(\mu \mathrm{m})\end{array}$ & $\begin{array}{c}\text { Resistance } \\
\text { for Two } \\
\text { Squares } \\
(X-\Omega)\end{array}$ & $\begin{array}{c}\text { Standard } \\
\text { Deviation }\end{array}$ & $\begin{array}{c}\text { Coefficient } \\
\text { of Variation } \\
\text { (percent) }\end{array}$ \\
\hline $1 \Omega / \mathrm{Sq}$. & $25 \pm 2$ & 2.5 & 0.282 & 11 \\
\hline $50 \Omega / \mathrm{Sq}$. & $25 \pm 2$ & 85.0 & 11.985 & 14 \\
\hline $1,000 \Omega / \mathrm{Sq}$. & $25 \pm 2$ & 1,500 & 0.110 & 7 \\
\hline $10,000 \Omega / \mathrm{Sq}$. & $25 \pm 2$ & 9,600 & 1.128 & 12 \\
\hline
\end{tabular}

\section{Aluminum Nitride Substrate}

Tx Regulator Temperature $=+73^{\circ} \mathrm{C}$

Thermal Chuck Temperature $=+67^{\circ} \mathrm{C}$

Temperature Difference $=+6^{\circ} \mathrm{C}$

\section{Alumina Substrate}

Tx Regulator Temperature $=+95^{\circ} \mathrm{C}$

Thermal Chuck Temperature $=+65^{\circ} \mathrm{C}$

Temperature Difference $=+30^{\circ} \mathrm{C}$

Temperature Reduction Using AIN $=24^{\circ} \mathrm{C}$ (80\% reduction in operating temperature).

Figure 11. Actual Test Temperatures

The technical requirement details for AIN thick film hybrid materials are displayed in Table A-1 in the Appendix.

\section{Accomplishments}

A new substrate material and 11 new inks were analyzed to determine their suitability for use in the manufacturing of high-power microcircuits with efficient thermal properties. Preliminary data indicated satisfactory results with most of the new materials. However, the capability to print resistors was abandoned because of the wide variation experienced in resistor values.

In addition to these determinations, this study also achieved the following results.

- Circuit operating temperature was shown to decrease by $24^{\circ} \mathrm{C}$ when the new substrate material was substituted for the standard substrate material in a complex thick film multilayer circuit.

- A technical partnership was successfully formed with two outside companies. 
- Technical requirements were established for AIN thick film materials.

- A preliminary characterization of laser trimming on a new series of resistor pastes was performed.

- Aging characteristics of the new resistor pastes were complisted for 1,000 hours on $1,50,100,1,000$, and $10,000 \mathrm{ohms} / \mathrm{square}$ resistor materials at $150^{\circ} \mathrm{C}$.

- Assembly techniques used on standard thick films were evaluated for AIN materials.

Overall, it was found that the properties of the new AIN resistor pastes were not as good as the properties of standard thick film resistors.

\section{Future Work}

Future activities should include additional AIN resistor evaluations. The Ferro Corporation is currently developing a more stable $100 \mathrm{ohm} / \mathrm{square}$ paste. Also, there was a design-related problem with the resistors on the Logic Networks that kept the resistors from being printed at controllable thicknesses. In addition to stability, parameters of interest should include sheet resistivity, temperature coefficient of resistance, percent coefficient of variation, and laser trimmability to nominal within a specified tolerance.

Concerning the AIN substrates, future activities should include additional studies on lot-to-lot effect on metallization adhesion to the substrate. 


\section{References}

1 Department of Defense Memorandum for Industry Distribution, "Request for Suitable Substitutes for Beryllium Oxide," February 6, 1989.

25. W. Bandler and L. H. Perdieu, Thick Film Multilayer AIN Power Hybrid Circuit. ISHM Proceedings, Dallas, TX, 1993.

${ }^{3}$ K. Allison, A. Shaikh, D. Leandri, M. Raymond, G. Ackerman, and D. Hankey, Thick Film Materials For Applications On Aluminum Nitride Substrates. IMC Proceedings, Tokyo, 1988.

${ }^{4}$ Y. Kurihara, S. Takahashi, K. Yamada, T. Endoh, and K. Kanai, Thick Film Resistors for AIN Ceramics, IEEE Transactions on Components, Hybrids, and Manufacturing Technology, Vol. 14, No. 1, March 1991. 


\section{Appendix}

\section{Test Data for AIN Microcircuits}




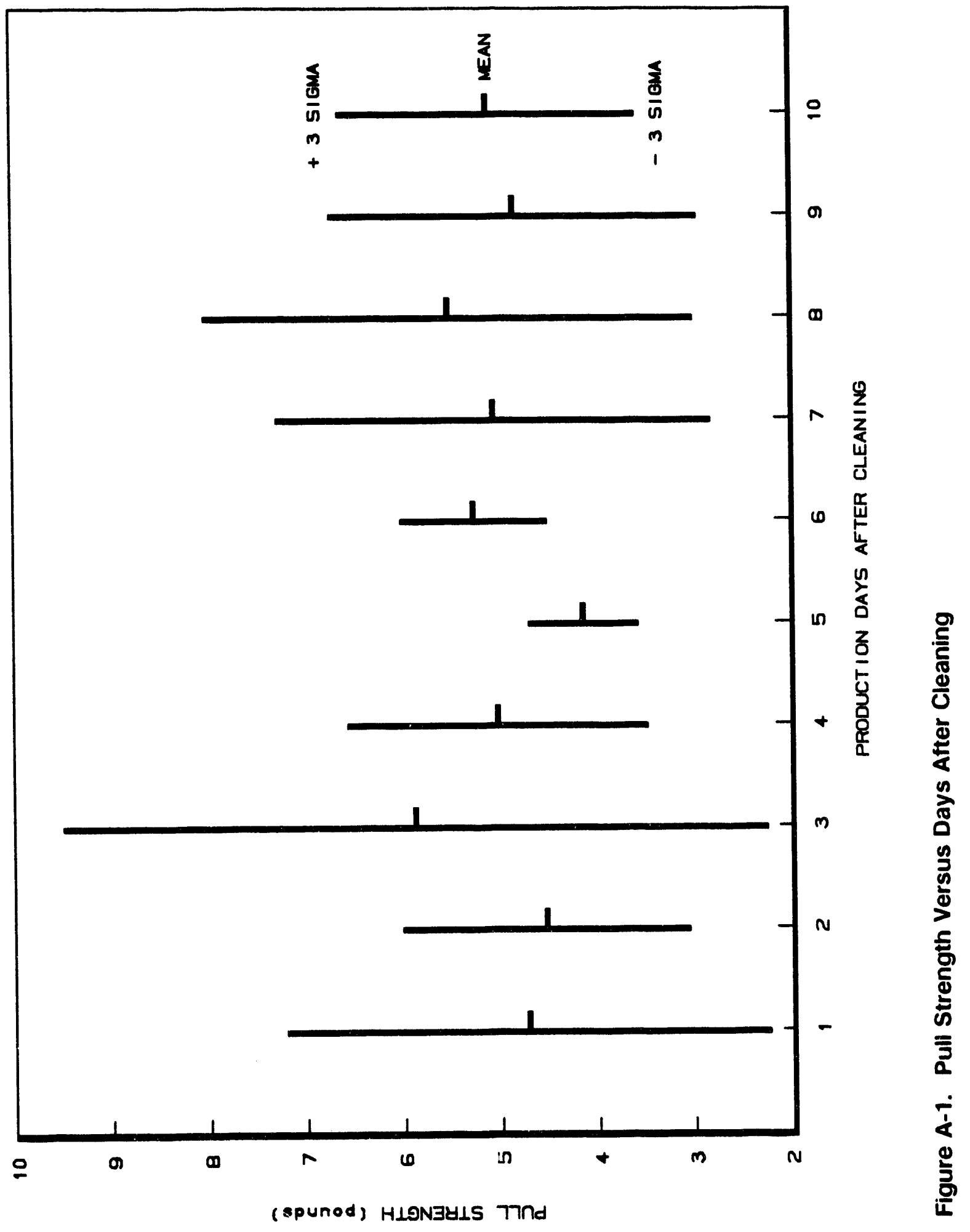




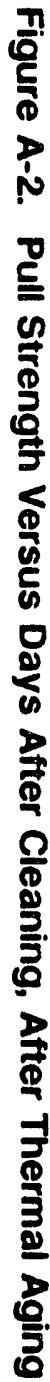

PULL STRENGTH (pounds)

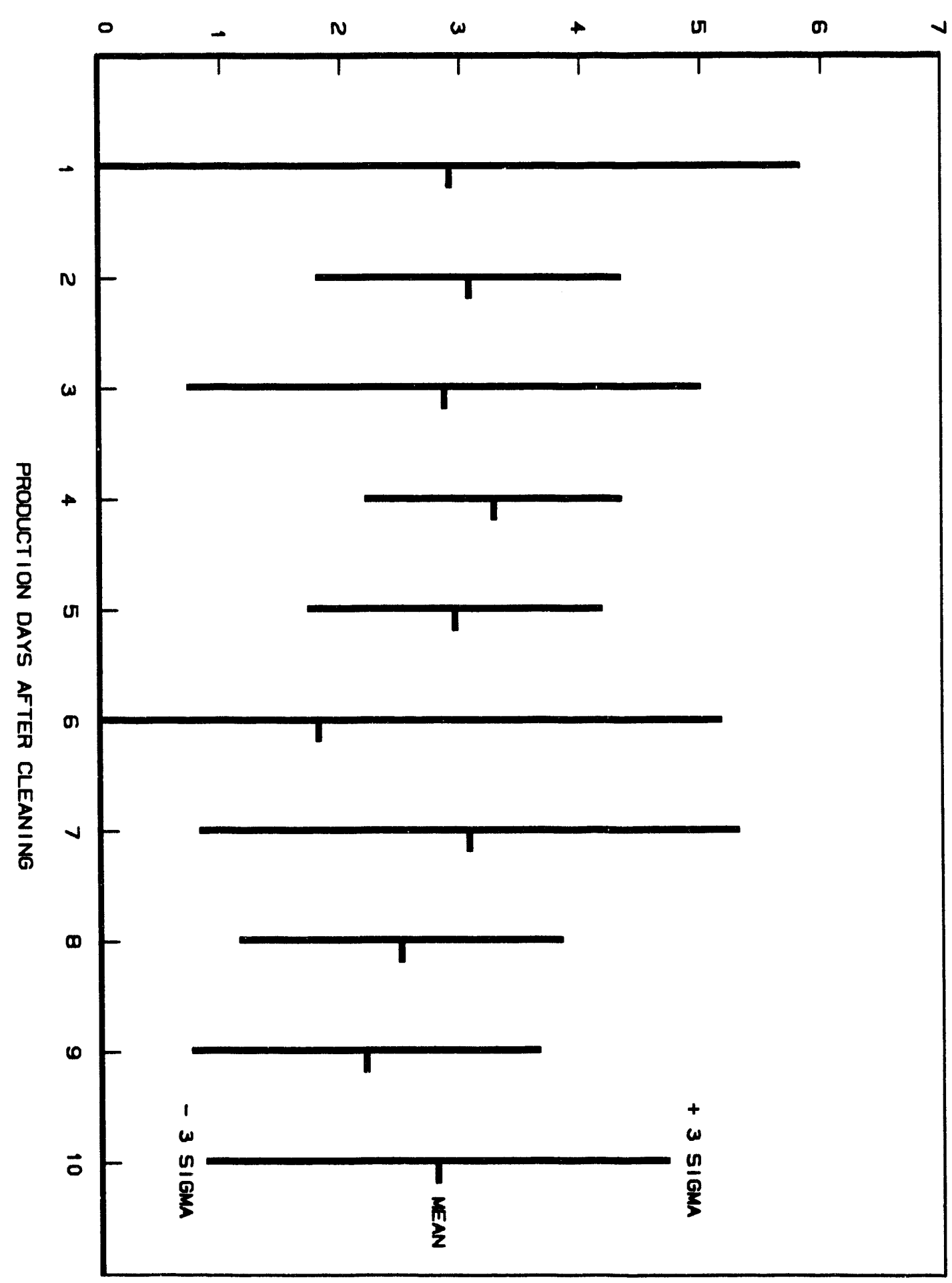




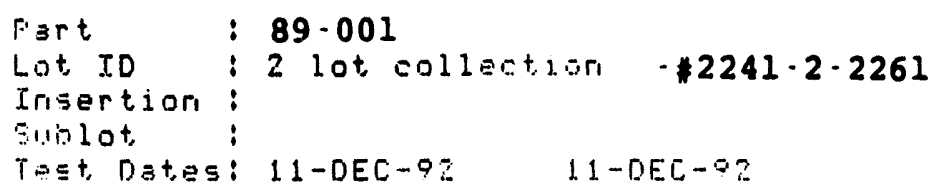

Figure A-3. CV Data for $1 \mathrm{Ohm} /$ Square Material 
Test urits: 0

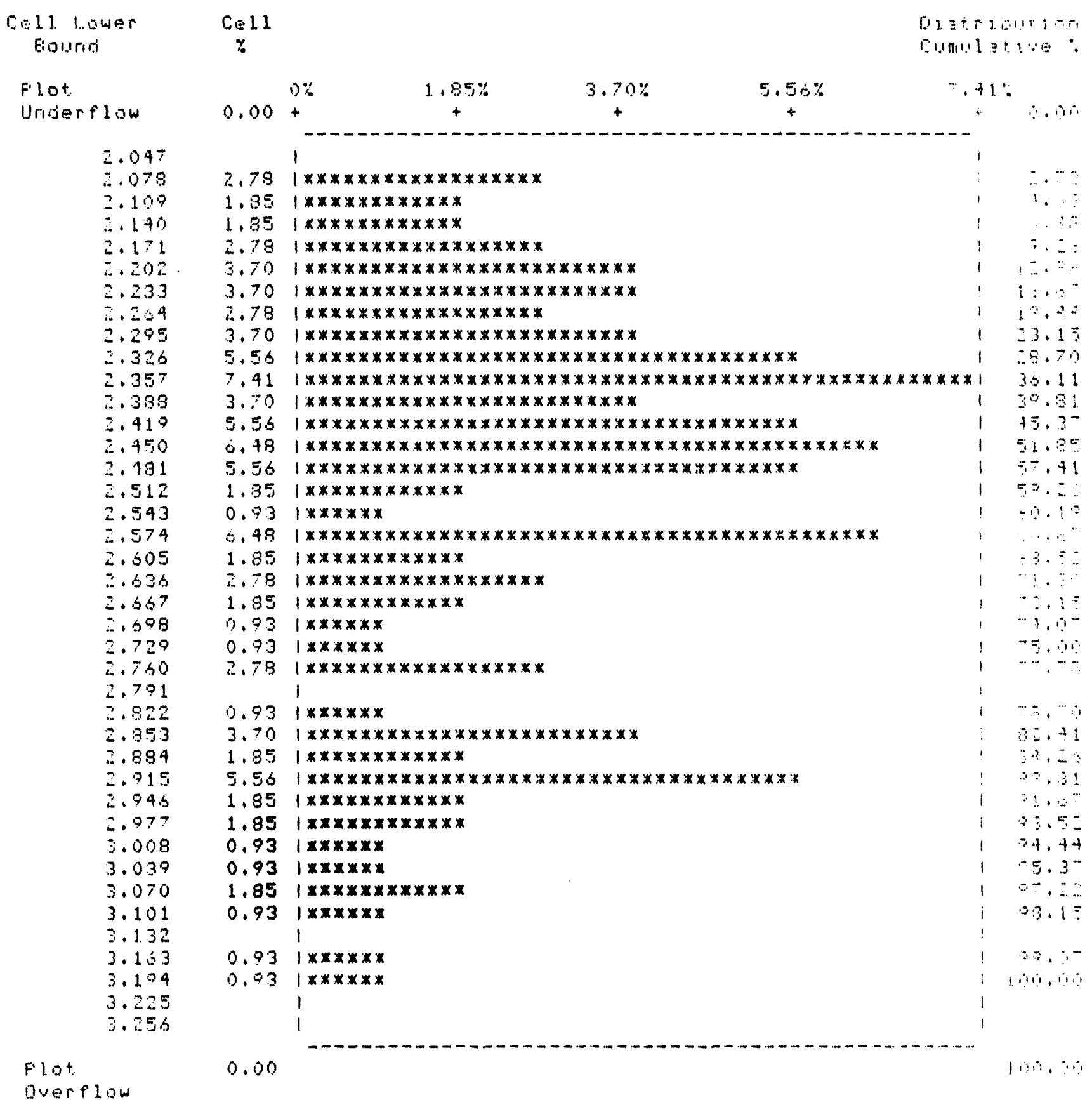

Figure A-4. Histogram for CV Data for $1 \mathrm{Ohm} / \mathrm{Square}$ Material 


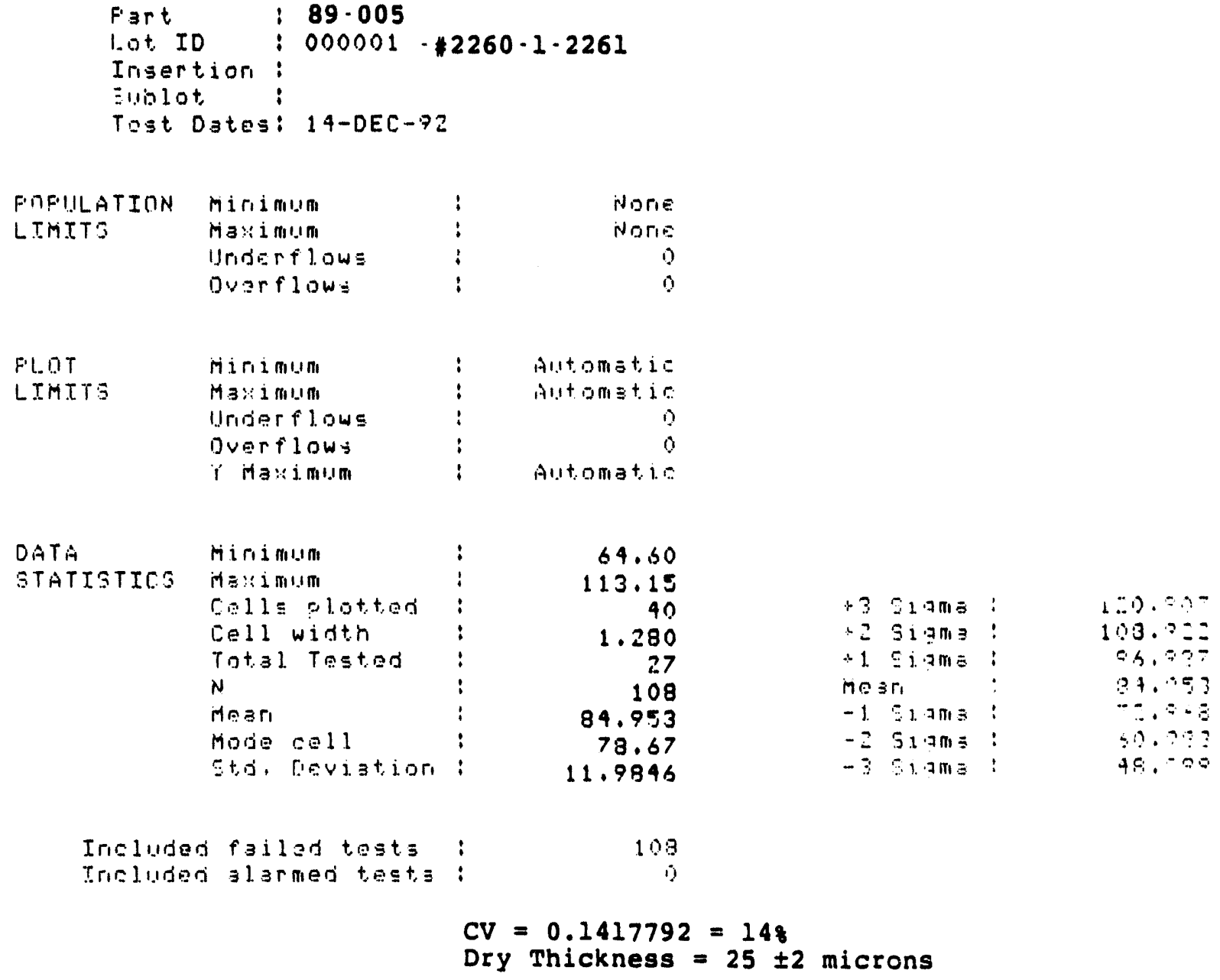

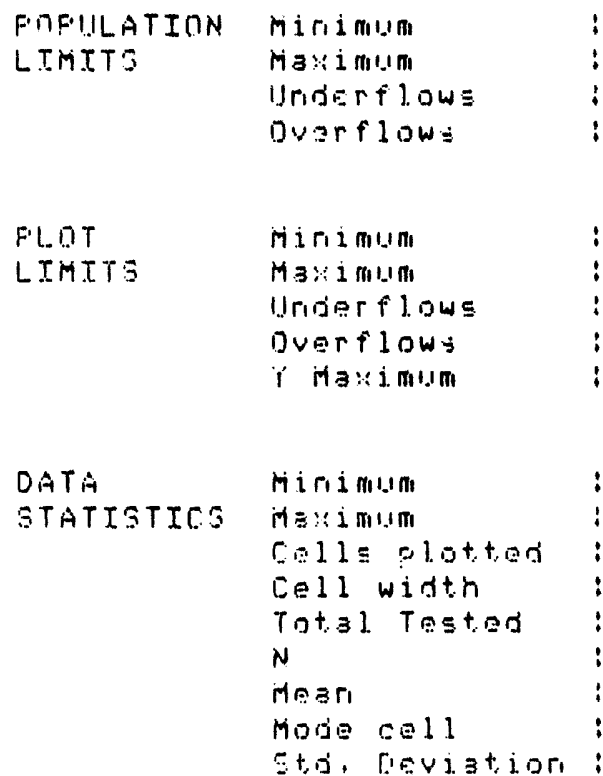

$\begin{array}{rr}\vdots & \text { Norie } \\ \vdots & \text { Norie } \\ \vdots & 0\end{array}$

Figure A-5. CV Data for 50 Ohms/Square Material 


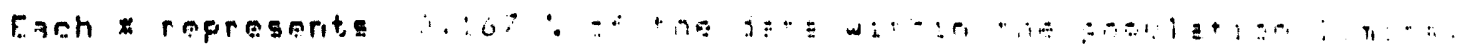

Test units : 0

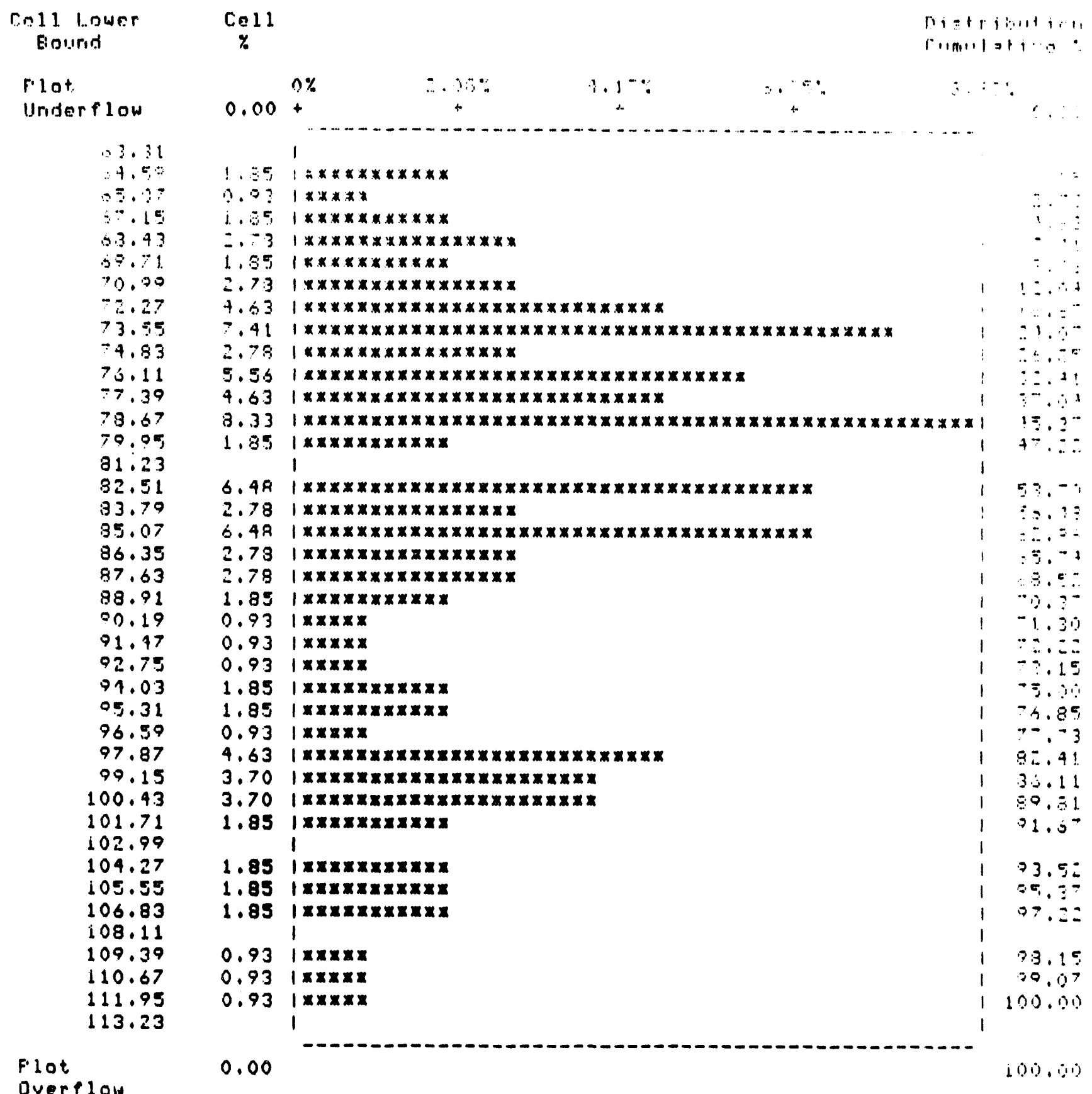

Figure A-6. Histogram for CV Data for $50 \mathrm{Ohms/Square} \mathrm{Material}$ 


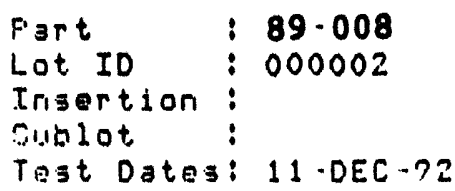

PMFULATION LIMTTS

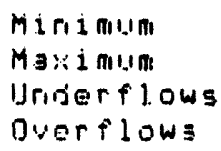

\section{Mi i ri millm}

its $3 x$ i mum

Colls plotted

Cell widtin

Total. Tested $N$

Mast

Mode cell

sto. Doviatjor :
Norie

Norie

0

int ismatic Alut,omat, ic

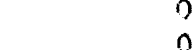

Alltomatio

$$
\begin{array}{r}
1.223 \\
1.807 \\
29 \\
0.0160 \\
27 \\
100 \\
1.5293 \\
1.580 \\
0.10995
\end{array}
$$

1.0541

$1,714=$

1. 6392

1. 354

1. . 11.2

1.3017

1. . 1944

Tricluded failad tasts:

108

Tricluger alarmed tests:

$$
\begin{aligned}
& C V=0.0721315=78 \\
& \text { Dry Thickness }=25 \pm 2 \text { microns }
\end{aligned}
$$

Figure A-7. CV Data for 1,000 Ohms/Square Material 
Test writs:

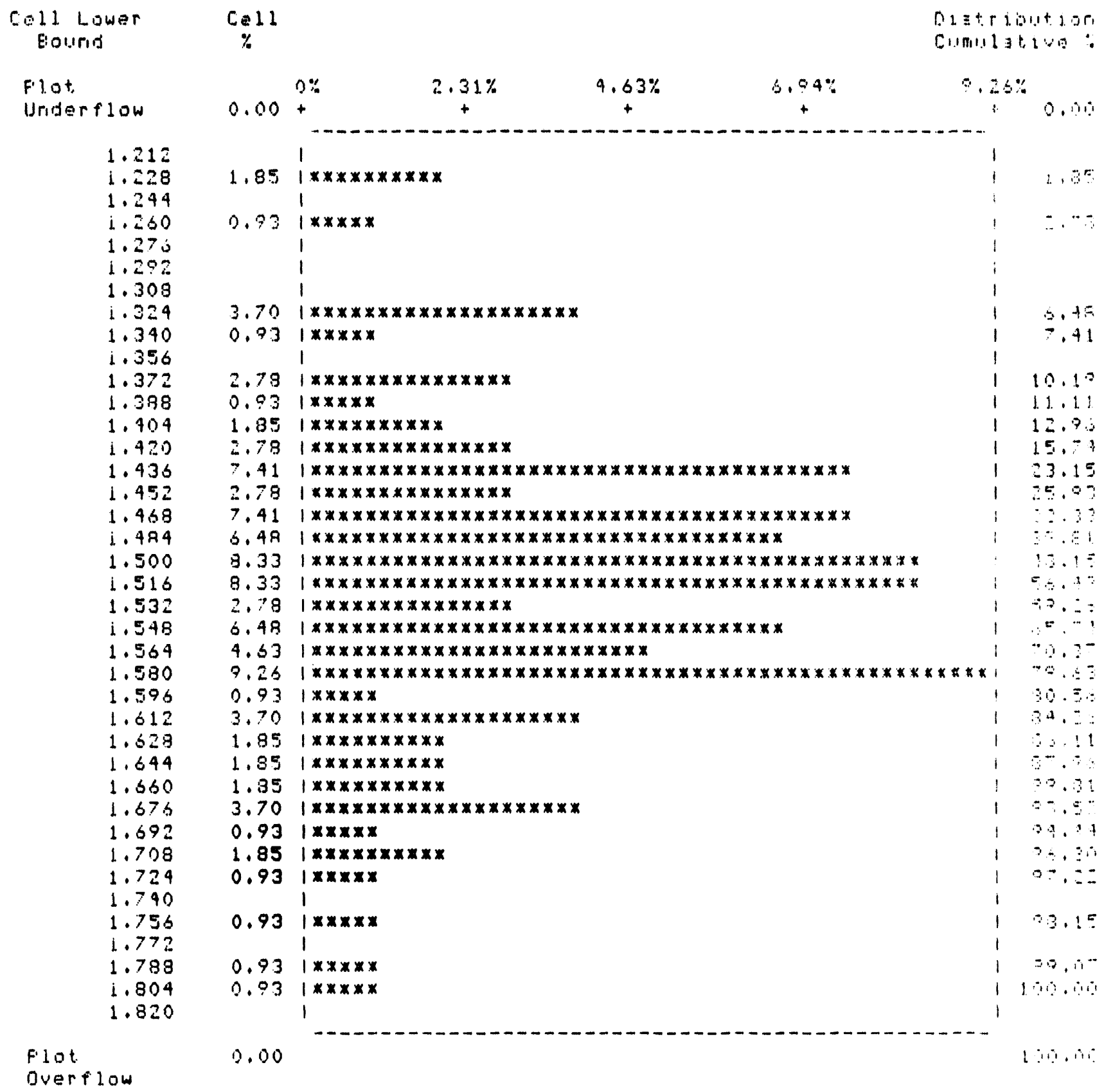

Figure A-8. Histogram for CV Data for 1,000 Ohms/Square Material 
Test units: Ko

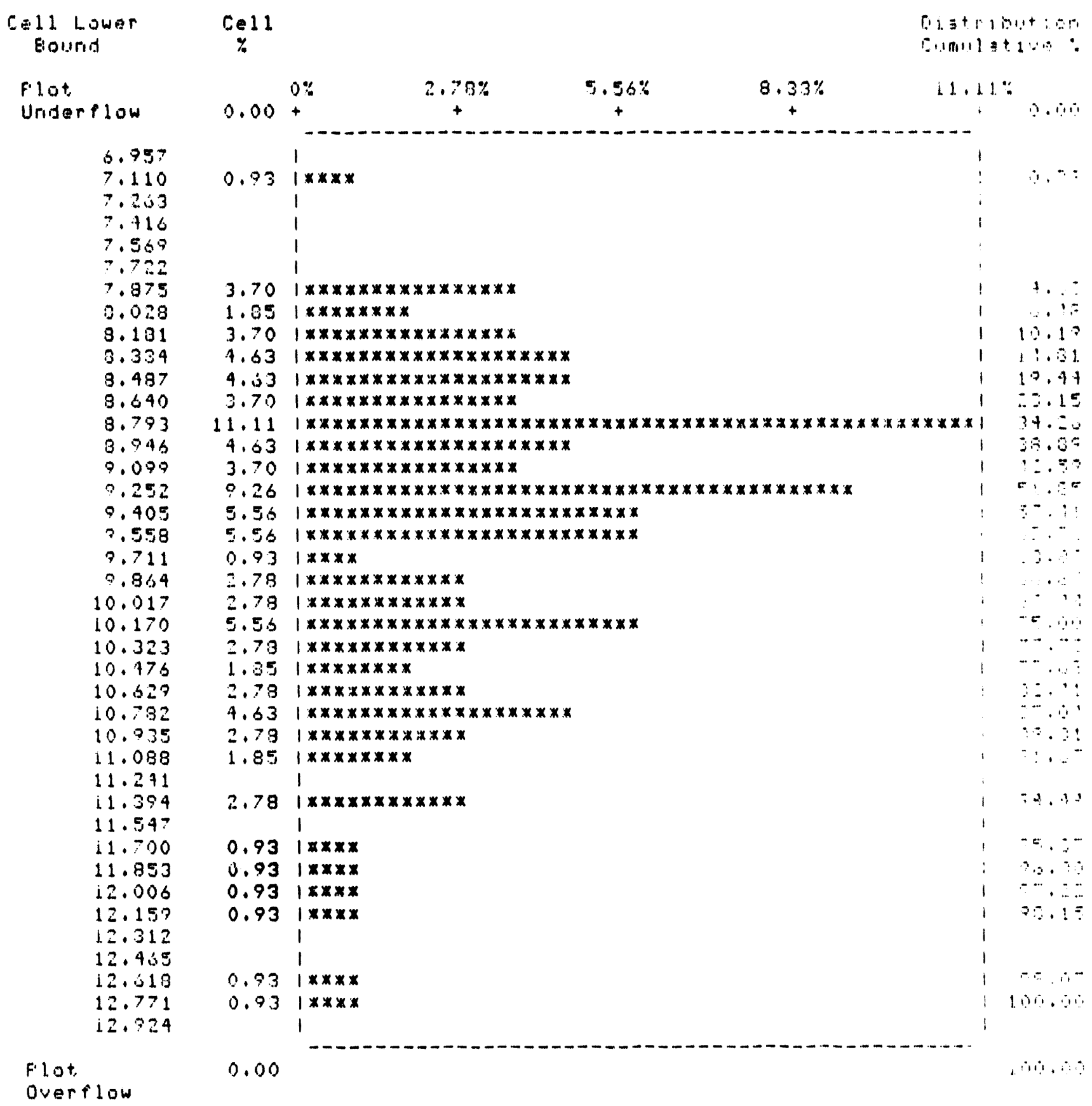

Figure A-10. Histogram for CV Data for $10,000 \mathrm{Ohms} / \mathrm{Square}$ Material 
Table A-1. Pre-established Requirements for AIN Thick Film Hybrid Materials

\begin{tabular}{|c|c|c|c|}
\hline \multicolumn{4}{|c|}{ Anything not otherwlee specified below will be teated to manufecturer's data sheet } \\
\hline 1 & \multicolumn{2}{|l|}{ Conductor Line Resolution } & $\begin{array}{l}5 \text { mill lines and spaces } \\
\text { After line has been printed and dried it } \\
\text { must maintain width of } \pm 1 \text { mil }\end{array}$ \\
\hline 2 & \multicolumn{2}{|l|}{ Conductor Thickness } & $0.4 \cdot 0.6 \mathrm{mll}$ \\
\hline 3 & \multicolumn{2}{|c|}{ Conductor Resistivity (1 mil fired thickness) } & $\begin{array}{ll}\text { (Au) } 3068 \mathrm{~N} & =4.0 \cdot 5.0 \mathrm{mohms} / \mathrm{sq} \\
\text { (Au) } 3086 & =2.0 \cdot 2.4 \mathrm{mohms} / \mathrm{sq} \\
\text { (Au) } 30-010 & =3.0 \cdot 4.0 \mathrm{mohm} / \mathrm{sq} \\
\text { (AU) } 30-011 & =5.5 \cdot 6.0 \mathrm{mohm} / \mathrm{sq} \\
\text { (PUAU) } 31-012 & =20-25 \mathrm{mohms} / \mathrm{sq} \\
\text { (PUAU) } 30-012 & =7.10 \mathrm{mohms} / \mathrm{sq}\end{array}$ \\
\hline 4 & \multicolumn{2}{|l|}{ Conductor Adhealon } & $\begin{array}{l}\text { Initial } \geq 6.0 \mathrm{lbs} \\
\text { Aged } \geq 4.0 \mathrm{lbs}\end{array}$ \\
\hline 5 & \multicolumn{2}{|l|}{ Must be able to coat vise walls } & Through-hole reaistance $\leq 4.5 \mathrm{lbs}$ \\
\hline 6 & \multicolumn{2}{|c|}{$\begin{array}{l}\text { Conductor Adheaion and Bondability Over } \\
\text { Dielectric } \\
31-009 \text { (double printed) and } 3068 \text { and } 3068 \mathrm{~N} \\
\text { (single printed) over dlelectric }\end{array}$} & $\begin{array}{l}\text { Initial Adheaion } \geq 4.5 \mathrm{lbs} \\
\text { Aged Adhesion } \geq 2.0 \mathrm{lbs}\end{array}$ \\
\hline 7 & \multicolumn{2}{|c|}{$\begin{array}{l}\text { Compatibility with Cleaning Mothods Used Prior } \\
\text { to Bonding \& Fluxleas Solder. } \\
\text { (1) Hydrogen Peroxide (Aqueous) } \\
\text { (2) Plasma } \\
\text { A) Oxygen } \\
\text { B) Nitrogen/Hydrogen } 97 / 3 \\
\text { C) Argon }\end{array}$} & \\
\hline 8 & \multicolumn{2}{|c|}{ 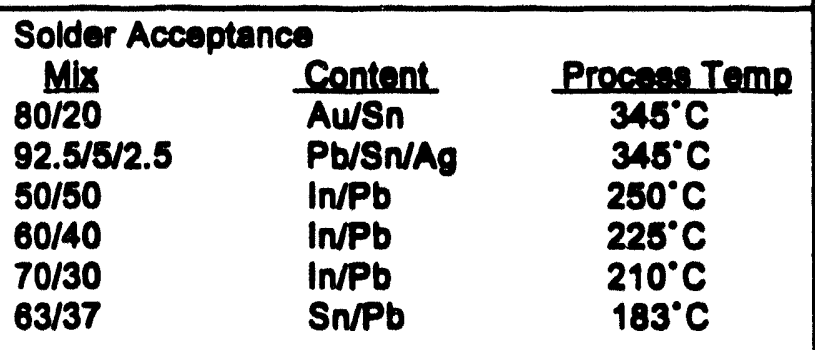 } & $\begin{array}{ll}\text { On AIN } & =98 \% \text { Wotting } \\
\text { On Diblectric } & =98 \% \text { Wotting }\end{array}$ \\
\hline
\end{tabular}


Table A-1 Continued. Pre-established Requirements for AIN Thick Film Hybrid Materials

Anything not otherwise specitted below will be teated to manufecturer's data sheet.

9. Bondability

- Metallization aystem(s) shall be capable of .001" pure gold wire bond atrengthe of 6 grams average, 3 grams minimum uaing a thermosonic ball bonding technique. using a substrate temporature of no more than $170^{\circ} \mathrm{C}$. Loop proflles prior to pull tosting shall be no more than $.015^{\prime \prime}$ in hoighe, and shall be no more than .025" in langth (bond to bond).

- Parallel gap welding (load frames)

- Motallization system(s) shall be capable of $.001^{*}$ and $.002^{*}$ aluminum (1\% allicon) ultrasonic wire bonding. Strongthe of 6 grams avorage and 2.5 grams avorage minimum for $.001^{-1}$ and 15 grams average and 5.6 grams minimum for $.002^{\circ}$ wires. Loop proflles prior to pull testing shall be no more than .015" in height and shall be no more than .025" in length (bond to bond) for $.001^{\circ}$ and $.050^{\prime \prime}$ in length (bond to bond) for $.002^{n}$ wire.

- Thermosonic gold ribbon bonding.

- Motallization systom(s) shall be capable of opoxy attachment tochniques using epoxios listed to the right. Curing profile shell be $160^{\circ} \mathrm{C}$ for 1.5 hours. Shear strengths shall be no lese than $1000 *$ /square inch.

1) Furane 7002

2) Furano $\mathbf{7 2 0 0}$

3) Ablo FIm 317

4) Able Flim 850

b) Epo-Tak H2OE

8) Epo-Tok H61

7) DuPont 5504

For the DuPont $5504 \approx 300^{\circ} \mathrm{C}$ for 1 hour temperature spike is added to the cure proflle.

10. PU/Au and Au conductors can be usad together on the samo lovel and cen overtap.

11. Raciator Stabillty (after trim) 4


Table A-1 Continued. Pre-established Requirements for AIN Thick Film Hybrid Materials

Anvthing not otherwise apecitiod below will be teated to menutcaturer's date shest.

\begin{tabular}{|c|c|c|}
\hline 12. & $\begin{array}{l}\text { Dielectric Requirements: } \\
\text { Insulation Reaistance (200 VDC) } \\
\text { Breakdown Voltage } \\
\text { Dielectric Constent }\end{array}$ & $\begin{array}{l}>10^{\prime \prime} \\
>600 \mathrm{~V} / \mathrm{mil} \\
8.0 \cdot 10.0\end{array}$ \\
\hline 13. & $\begin{array}{l}\text { Substrate Requirements: } \\
\text { Diolectric Constant } \\
\text { Volume Resiativity } \\
\text { Dielectric Loss } \\
\text { Thermal Conductivity } \\
\text { TCE } \\
\text { Donsity } \\
\text { Grain Slze } \\
\text { Camber } \\
\text { Surface Roughnose } \\
\text { Thickness } \\
\text { Bending Strength }\end{array}$ & $\begin{array}{l}8.6 \pm .1 \text { (at } 1 \mathrm{MHz} \text { ) } \\
210^{14^{4}} \\
.0005 \mathrm{Max} \text { (at } 1 \mathrm{MHz} \text { ) } \\
>170 \mathrm{~W} / \mathrm{mK} \\
4.7 \times 10^{-4} /{ }^{\circ} \mathrm{C} \\
3.3 \mathrm{~g} / \mathrm{cm}^{3} \\
3-8 \mathrm{mlorometers} \\
5.003^{-1 / n c h} \\
<25 \mathrm{microinches} \\
25 \pm 2.5 \mathrm{mil} \\
276 \mathrm{MPa}\end{array}$ \\
\hline
\end{tabular}



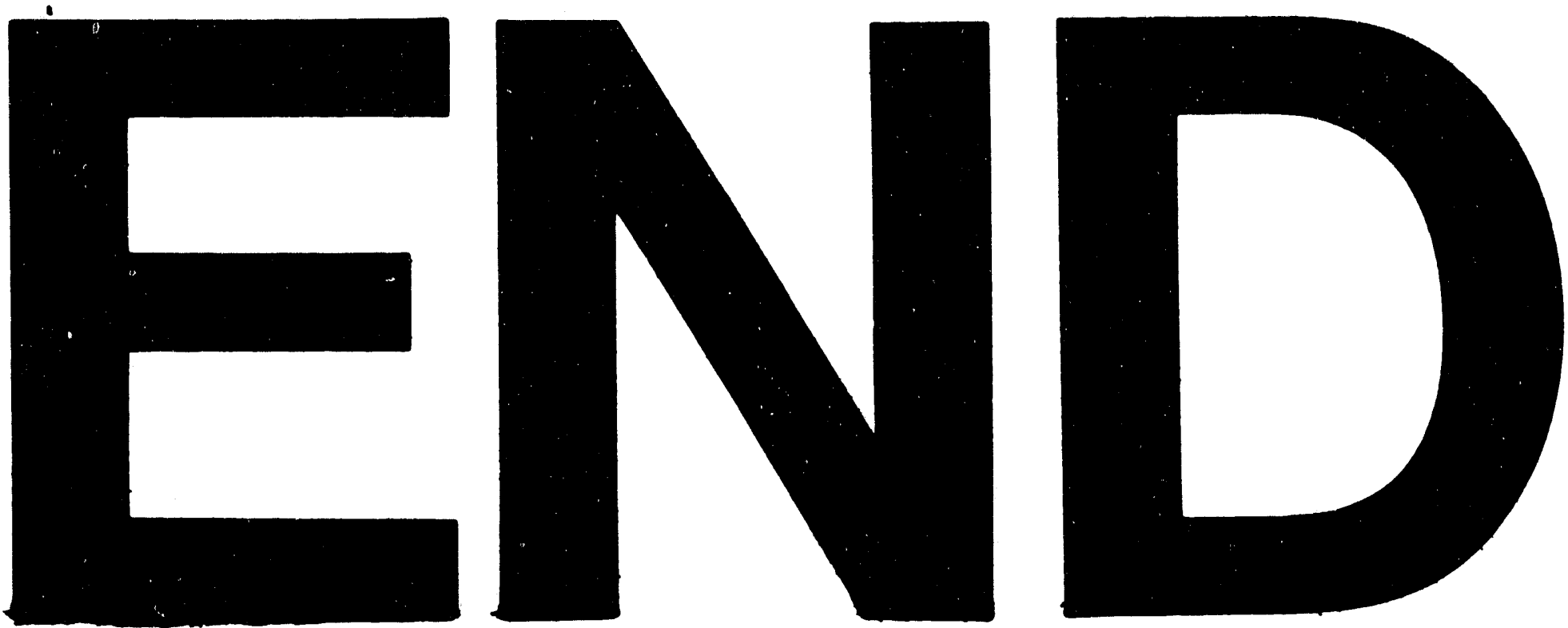

$\$$
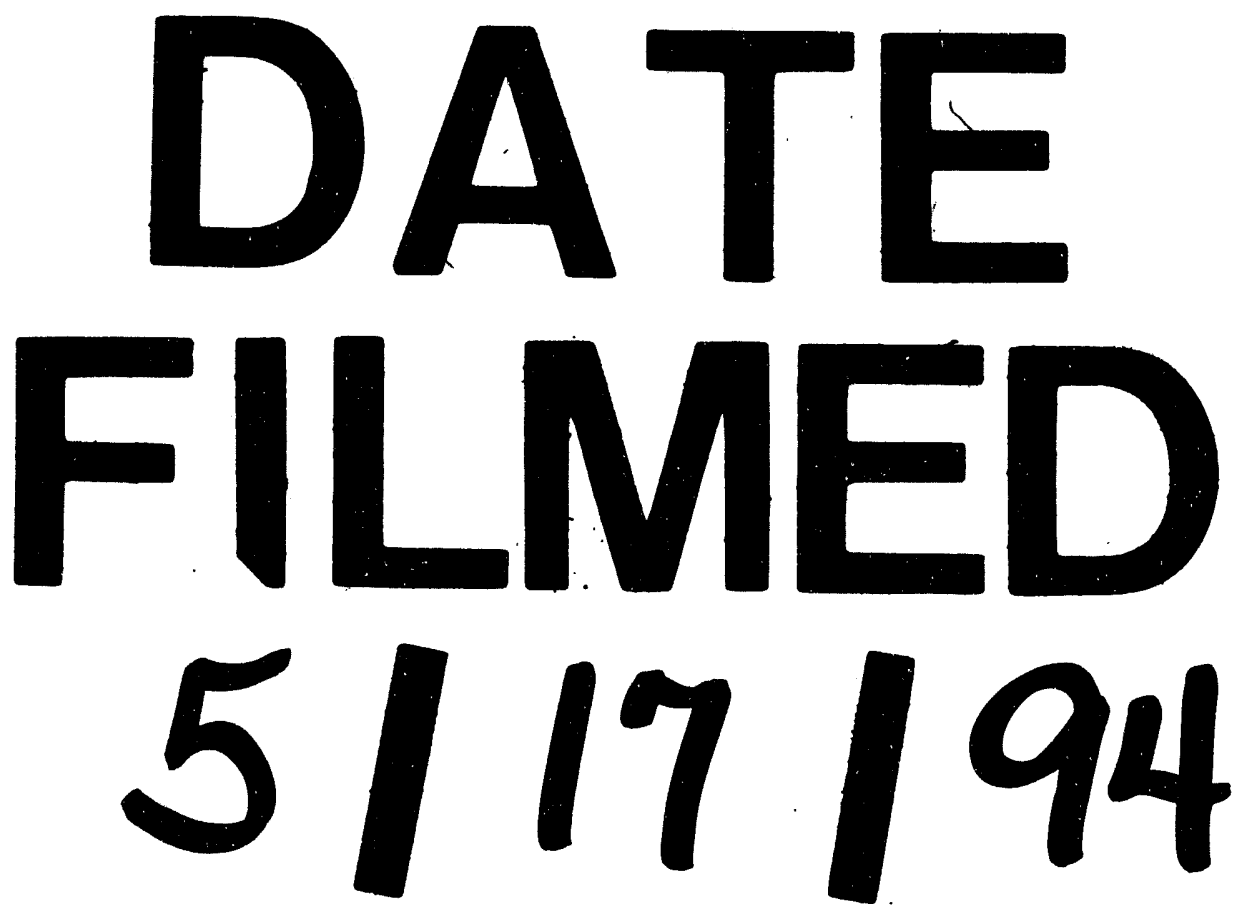
